\title{
Comments on the Bahamian evidence for superstorms during the last interglacial
}

John E. Mylroie, Department of Geosciences, Mississippi State, MS 39762 mylroie@geosci.msstate.edu

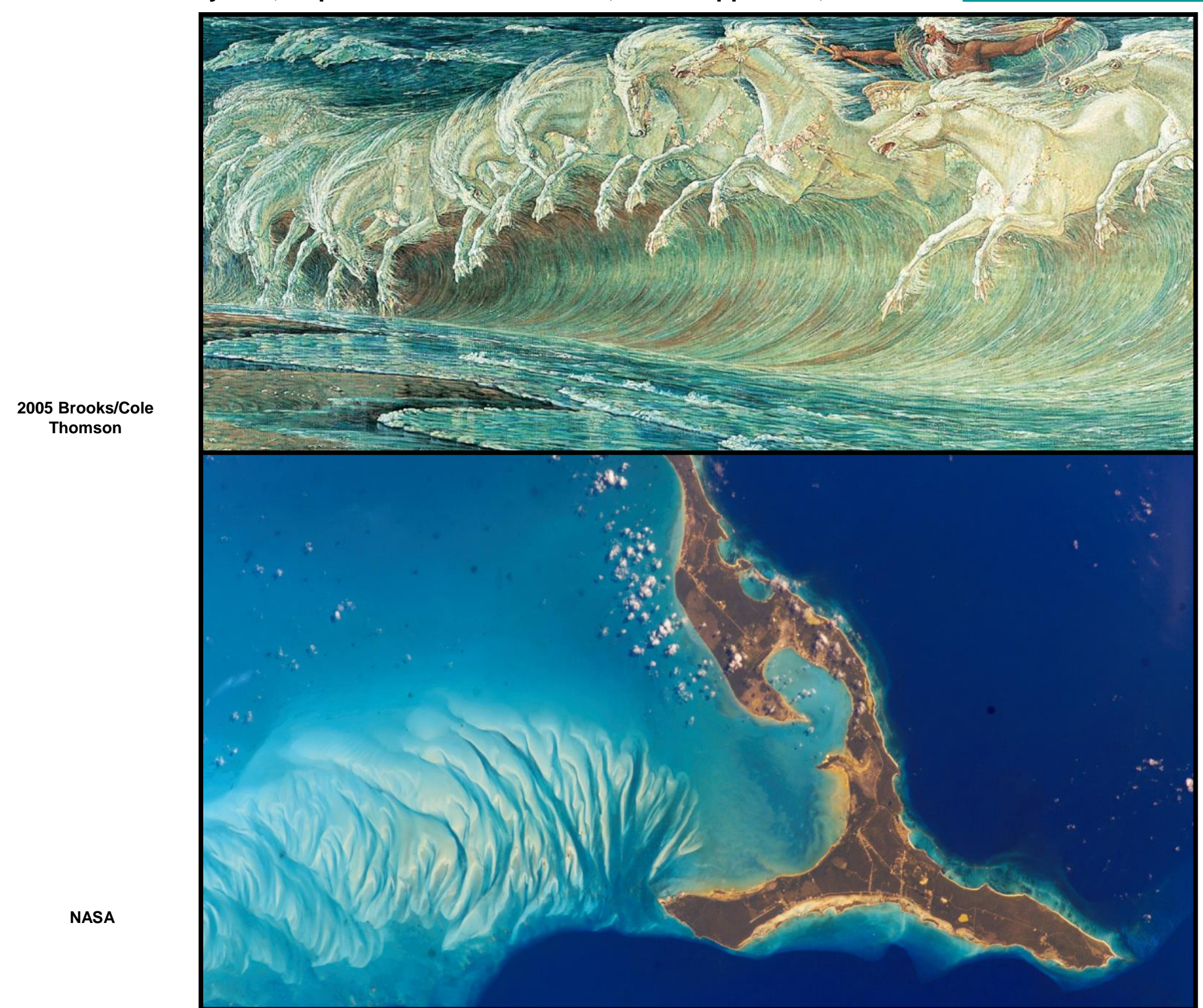


Comments on the Bahamian evidence for superstorms during the last interglacial John E. Mylroie, Department of Geosciences, Mississippi State, MS 39762 mylroie@geosci.msstate.edu

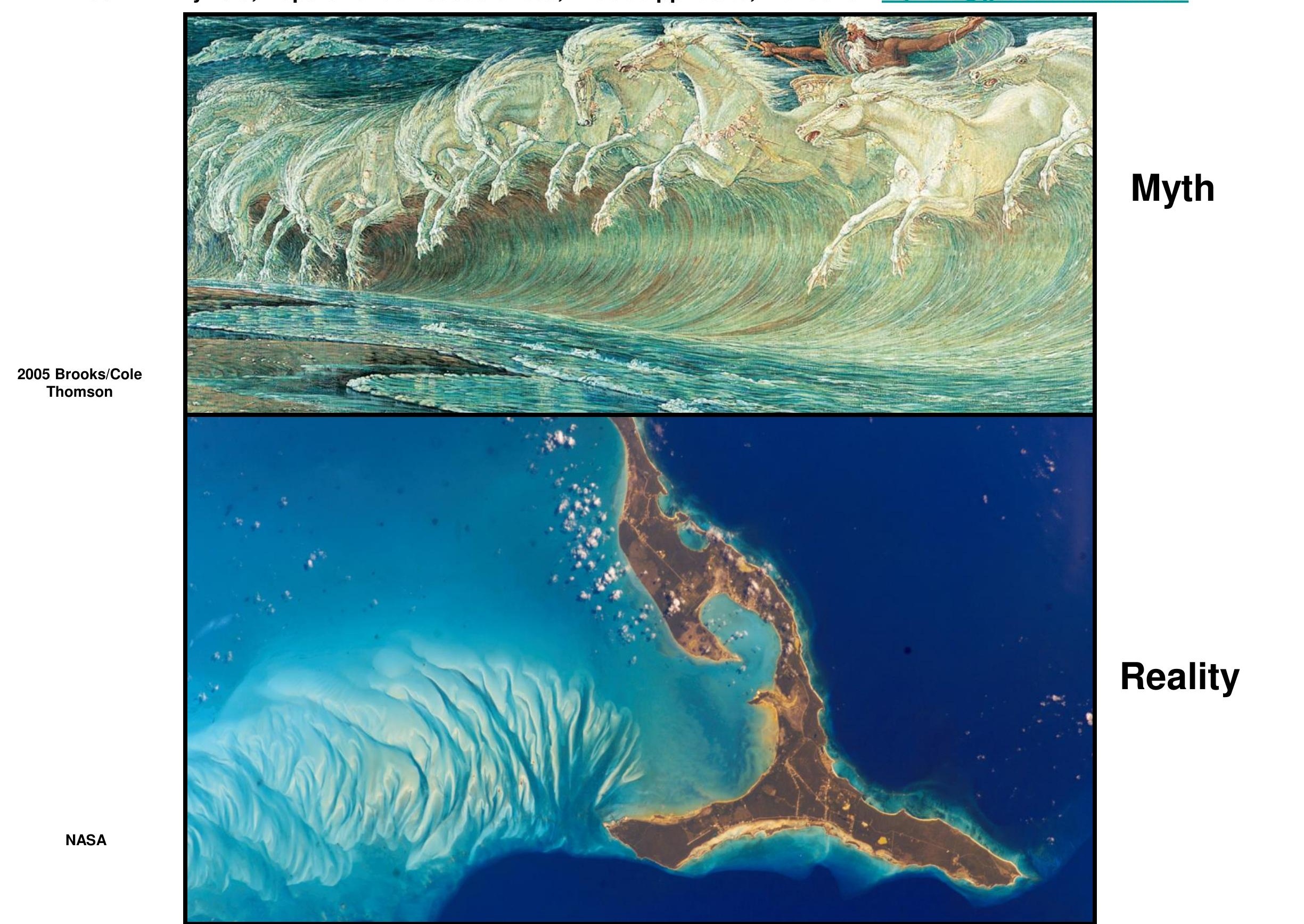


THE STORM IS UP, AND ALL IS ON THE HAZARD: IMPLICATIONS OF EXTREME STORM DEPOSITS IN THE BAHAMAS DURING THE LAST INTERGLACIAL

Tormey, B. R. 2015, GSA Abstracts With Programs, v. 47, no. 7, p. 360

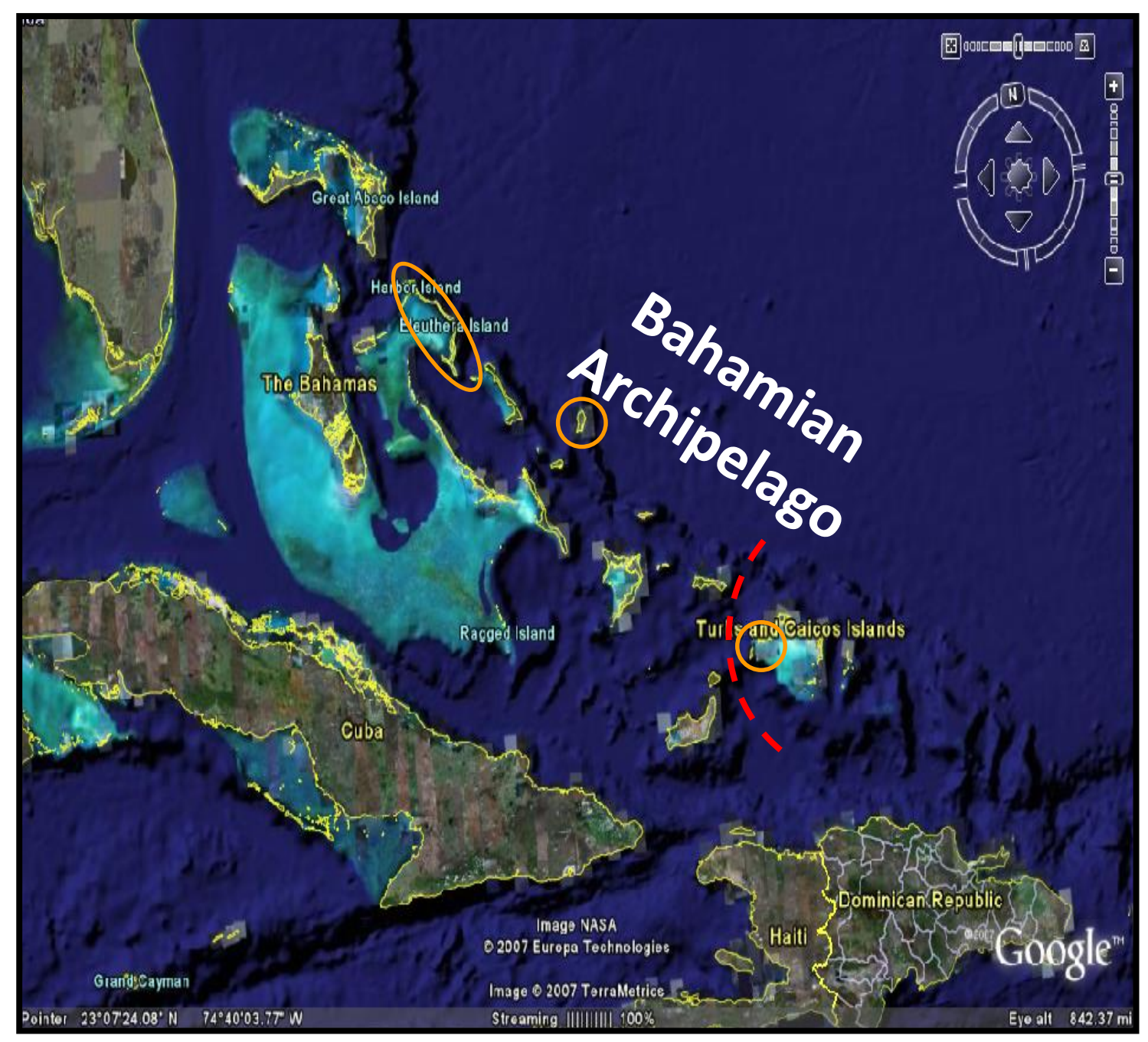


THE STORM IS UP, AND ALL IS ON THE HAZARD: IMPLICATIONS OF EXTREME STORM DEPOSITS IN THE BAHAMAS DURING THE LAST INTERGLACIAL

Tormey, B. R. , 2015, GSA Abstracts With Programs, v. 47, no. 7, p. 360

1. Fenestral porosity exists at elevations up to $43 \mathrm{~m}$ in The Bahamas. 
THE STORM IS UP, AND ALL IS ON THE HAZARD: IMPLICATIONS OF EXTREME STORM DEPOSITS IN THE BAHAMAS DURING THE LAST INTERGLACIAL

Tormey, B. R. , 2015, GSA Abstracts With Programs, v. 47, no. 7, p. 360

1. Fenestral porosity exists at elevations up to $43 \mathrm{~m}$ in The Bahamas.

2. The fenestral porosity was produced by storm wave wash-over. 
THE STORM IS UP, AND ALL IS ON THE HAZARD: IMPLICATIONS OF EXTREME STORM DEPOSITS IN THE BAHAMAS DURING THE LAST INTERGLACIAL

Tormey, B. R. , 2015, GSA Abstracts With Programs, v. 47, no. 7, p. 360

1. Fenestral porosity exists at elevations up to $43 \mathrm{~m}$ in The Bahamas.

2. The fenestral porosity was produced by storm wave wash-over.

3. Scour and rip-ups [sic] exist, cross beds and root structures diminished. 
Bain, R. J., 1985, Eolian Dune, Watling Roadcut. In Curran, H. A., ed., Pleistocene and Holocene carbonate environments on San Salvador Island, Bahamas - Guidebook for Geological Society of America, Orlando annual meeting field trip, p. 129-132.
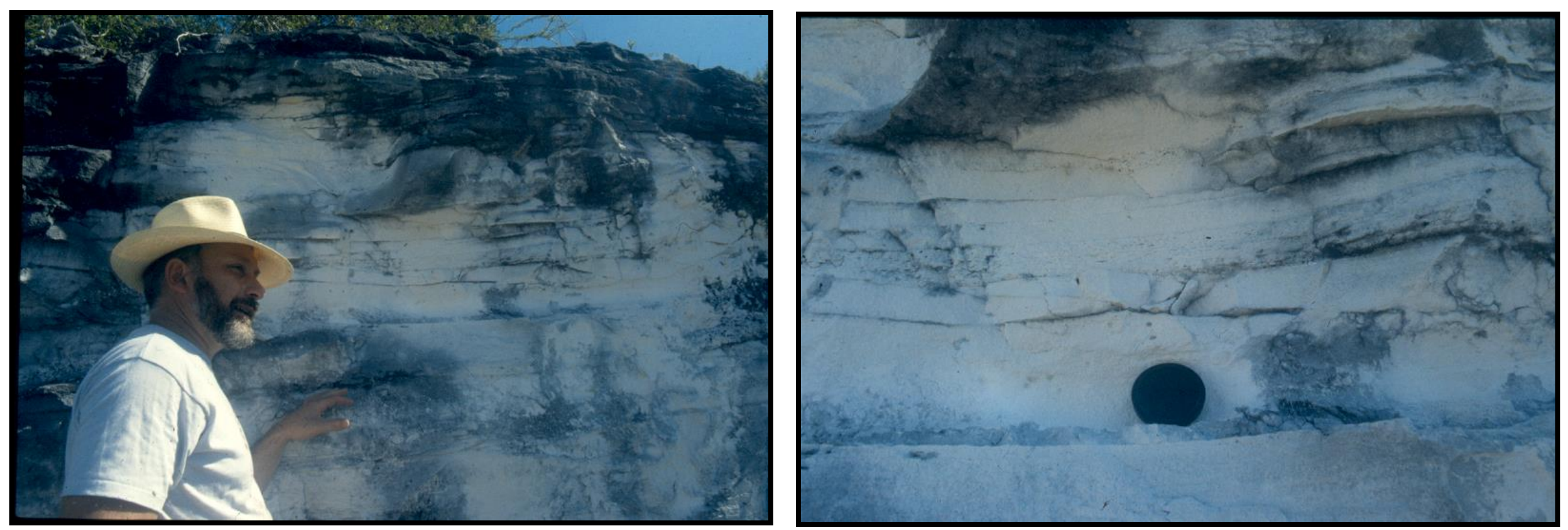

Roger Bain, October 1985, discussing fenestral porosity, Watling Road Cut, San Salvador Island, Bahamas 
Bain proposed that the fenestrae resulted from rainfall slurries, which would place them repeatedly in section, at a variety of elevations that need not correlate with each other.

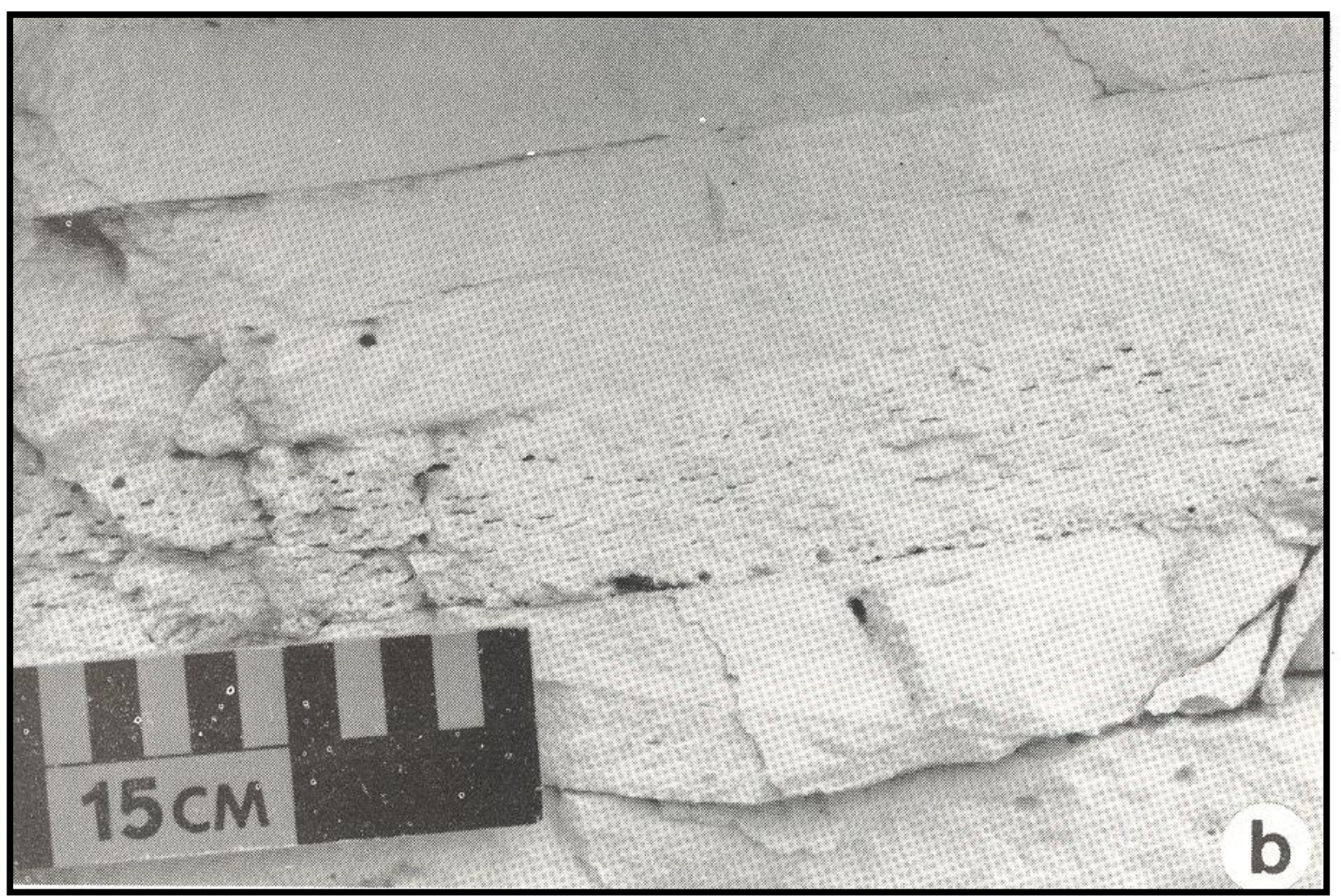

Close up of fenestral porosity, Watling Roadcut, San Salvador Island, from Bain, R. J., 1985 
Bain, R. J., 1985, Eolian Dune, Watling Roadcut. In Curran, H. A., ed., Pleistocene and Holocene carbonate environments on San Salvador Island, Bahamas - Guidebook for Geological Society of America, Orlando annual meeting field trip, p. 129-132.
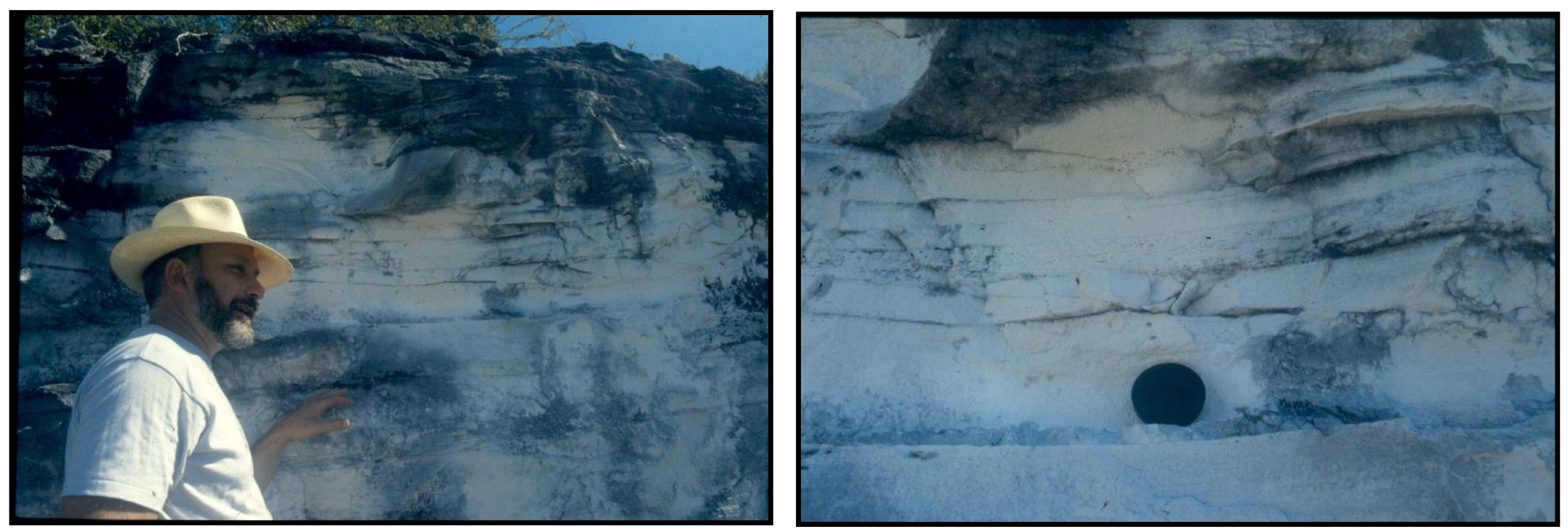

Roger Bain, October 1985, discussing fenestral porosity, Watling Road Cut, San Salvador Island, Bahamas

Bain, R.J., and Kindler, P., 1994, Irregular fenestrae in Bahamian eolianites: a rainstorm-induced origin: Journal of Sedimentary Research, v. 64, 140-146. 
Problems with the storm surge hypothesis:

1. To place storm run-up at 20,30 or $40 \mathrm{~m}$ above MIS $5 e$ sea level $(+6 \mathrm{~m})$ requires inundating all lower elevations. 
Storm run-up to $43 \mathrm{~m}(\sim 140 \mathrm{ft})$ requires all lower elevations shown to be submerged, especially if proximal to the east coast.

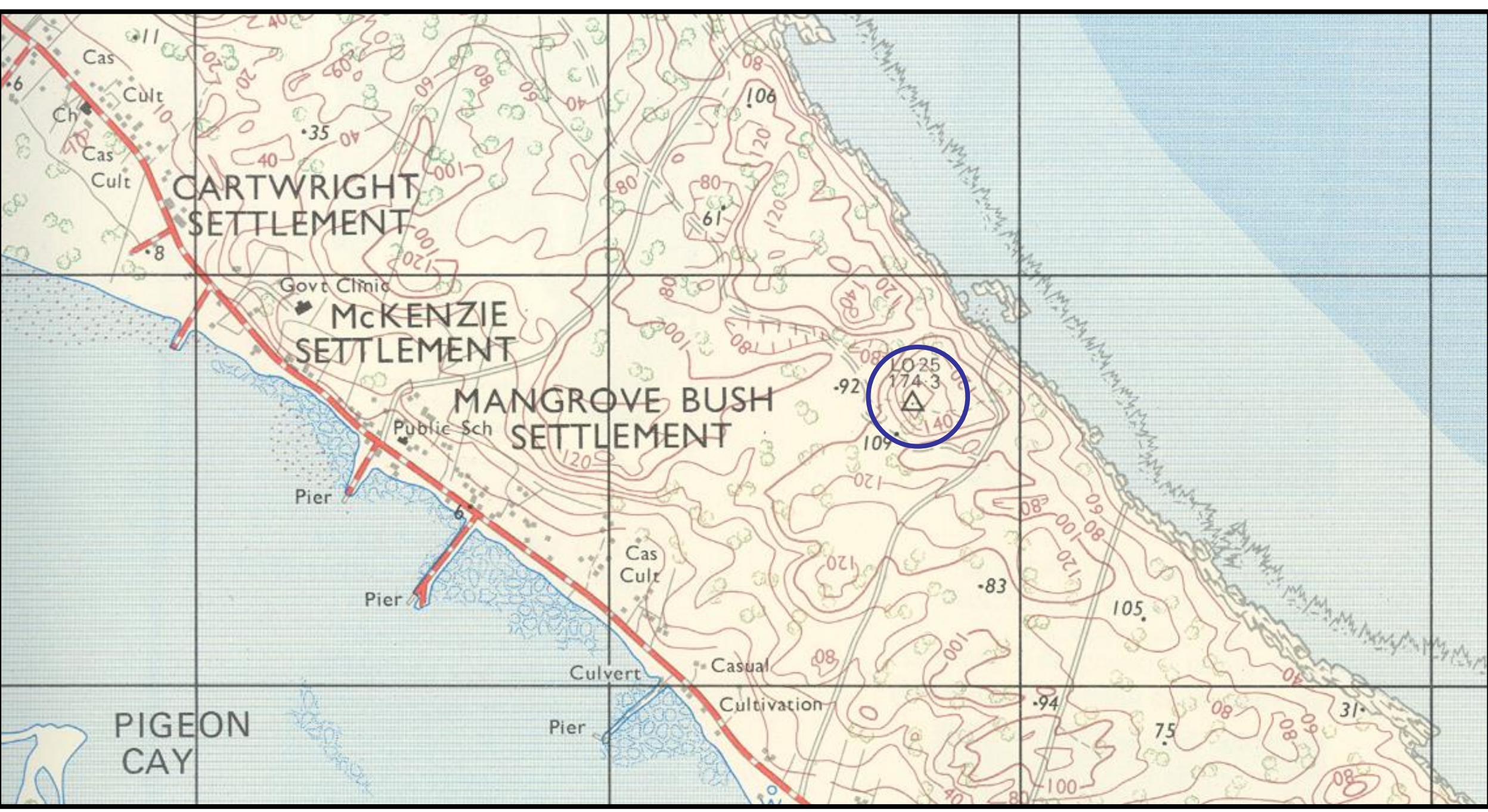

Long Island Bahamas, Map Sheet 5, Lands \& Surveys Department, Nassau, Bahamas, 1970 
Problems with the storm surge hypothesis:

1. To place storm run-up at 20,30 or $40 \mathrm{~m}$ above MIS 5 e sea level $(+6 \mathrm{~m})$ requires inundating all lower elevations.

2. Such inundation should leave behind a tempestite record. 
Bahamian tempestites are rare, but consist of unsorted, rounded clasts, boulder size to sand size, with sharp contacts with underlying and overlying units.

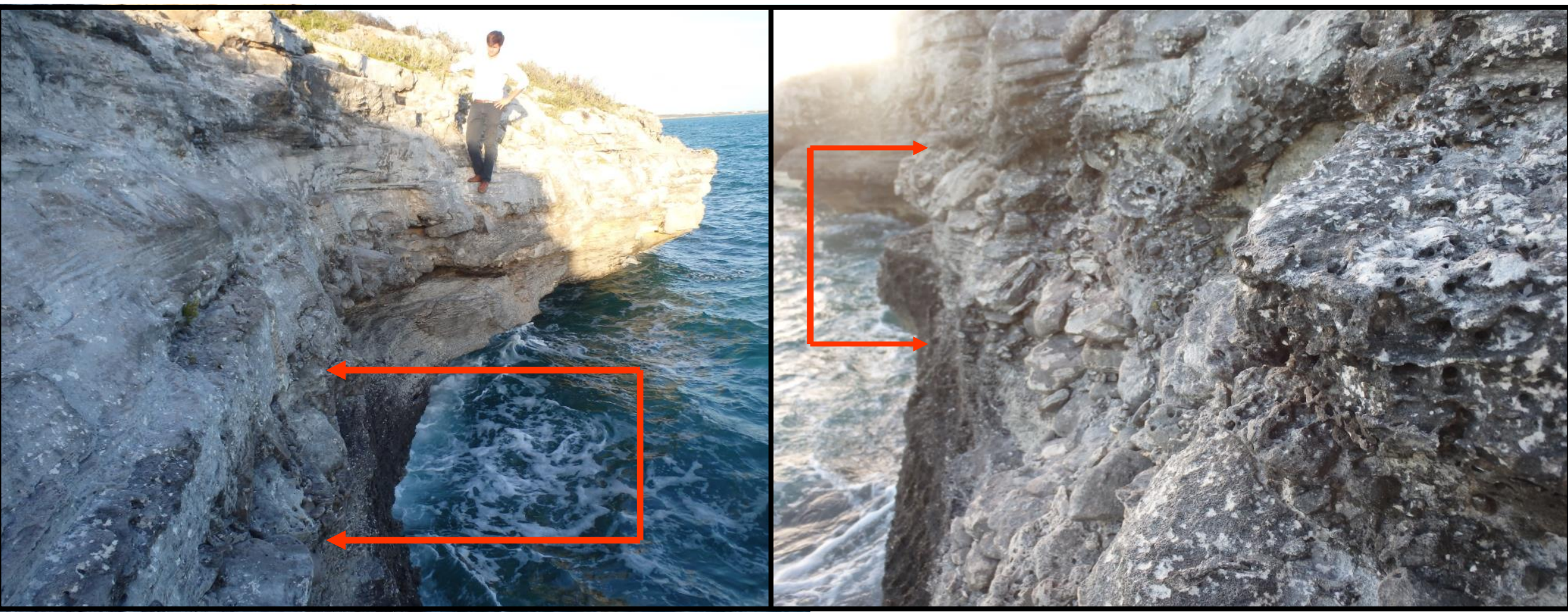

West Harbour Bluff, southern shore, Providenciales, Turks and Caicos 


\section{In addition to containing rounded unsorted clasts of large size, Bahamian tempestites contain abundant marine shell material and corals.}

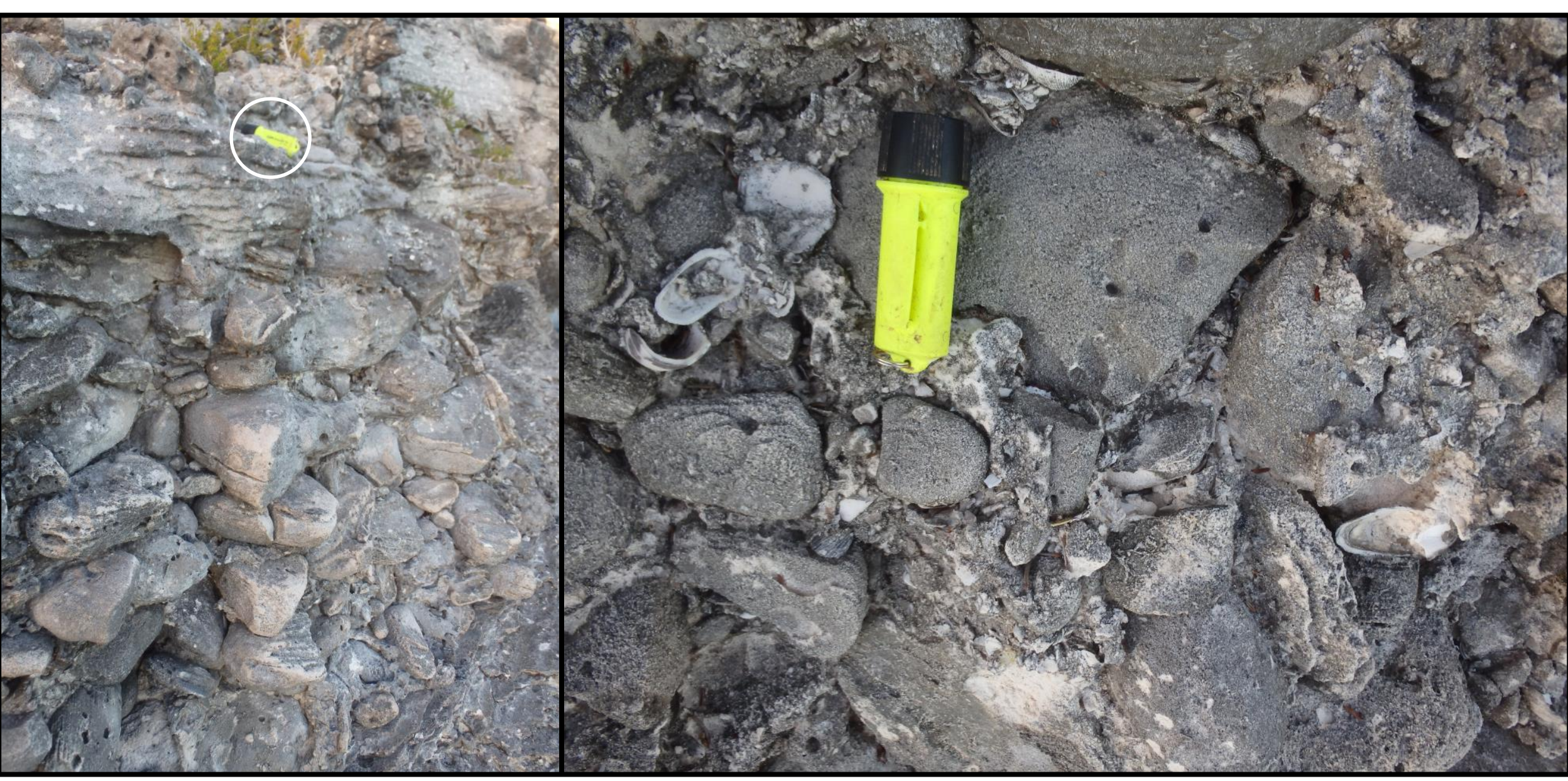

West Harbour Bluff, southern shore, Providenciales, Turks and Caicos

Flashlight $7 \mathrm{~cm}$ long for scale 


\section{Tempestites should have a large footprint. The example at West Harbour Bluff wraps around Split Rock into Pirate's Cove, a distance of $>1 \mathrm{~km}$.}

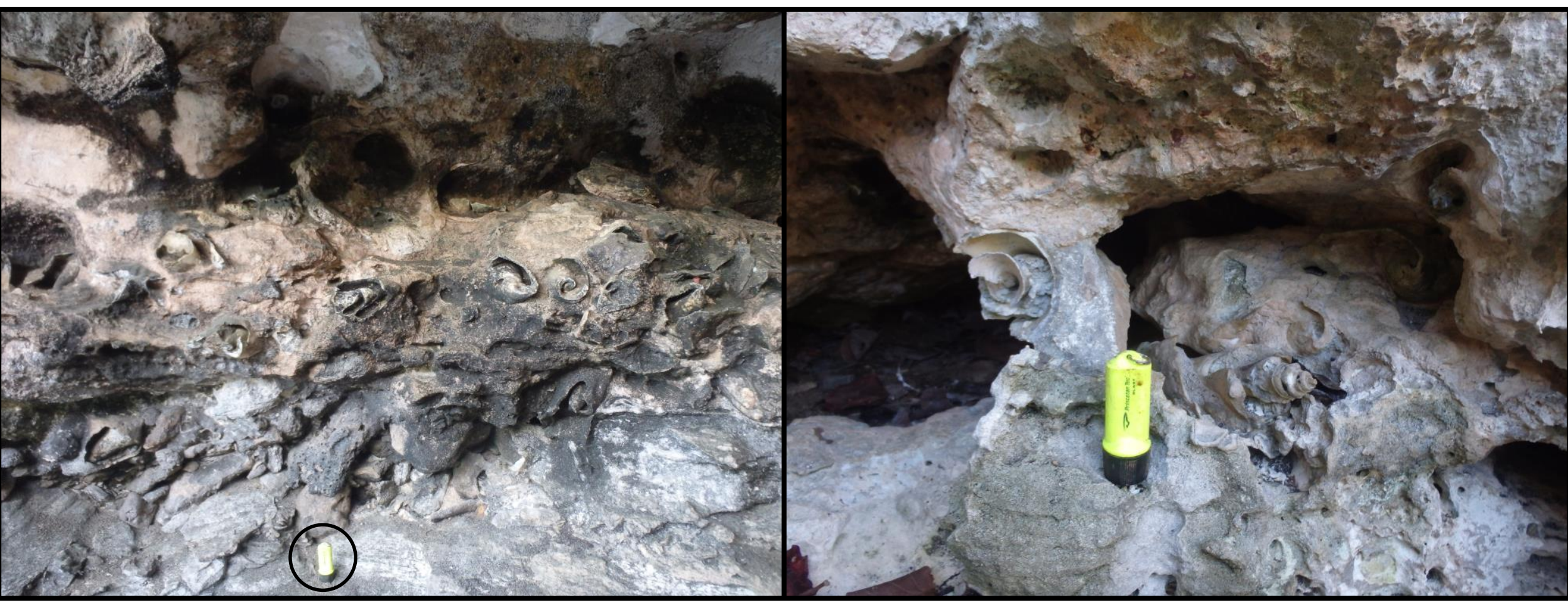

West Harbour Bluff Cave, western shore, Providenciales, Turks and Caicos

Flashlight $7 \mathrm{~cm}$ long for scale 
Clasts, mis-interpreted as storm surge "rip-ups", are the result of exposure surface weathering (red arrows) in a calcarenite protosol.

Fossil shell material here are land snails (orange arrows)

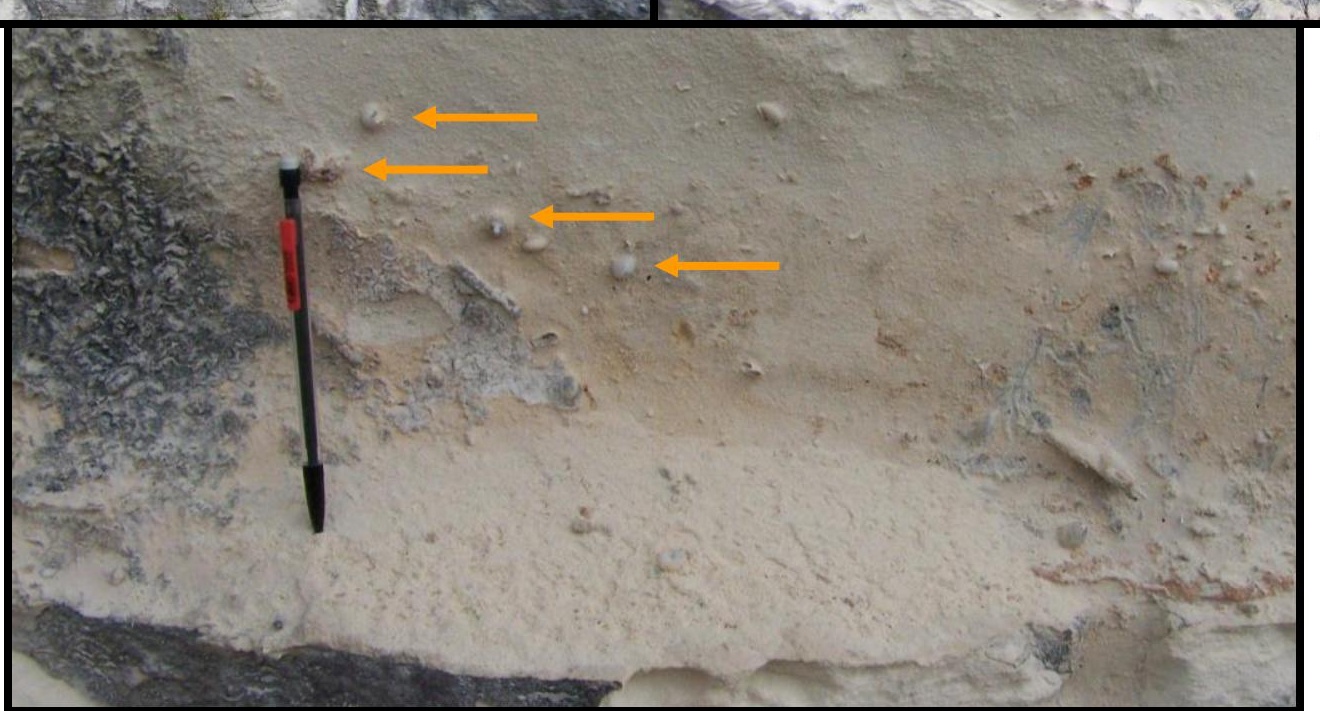

Twin Pines Road Cut, central Eleuthera 
Transgressive-phase eolianites have bedding that is well-preserved with few vegemorphs.

North Point, Holocene, San Salvador Island

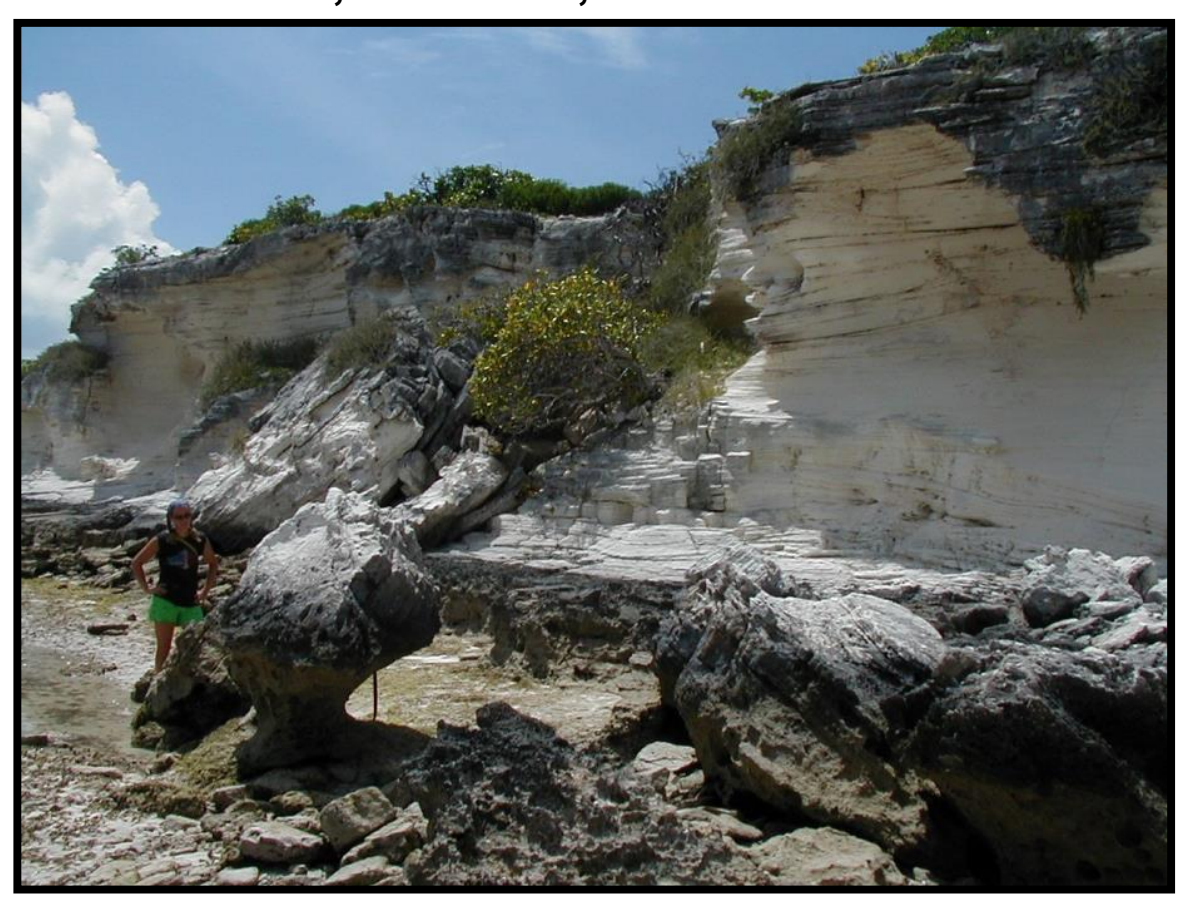

Regressive-phase eolianites have disrupted bedding high in the section, with well-developed vegemorphs

\section{Crab Cay, Pleistocene, San Salvador island}

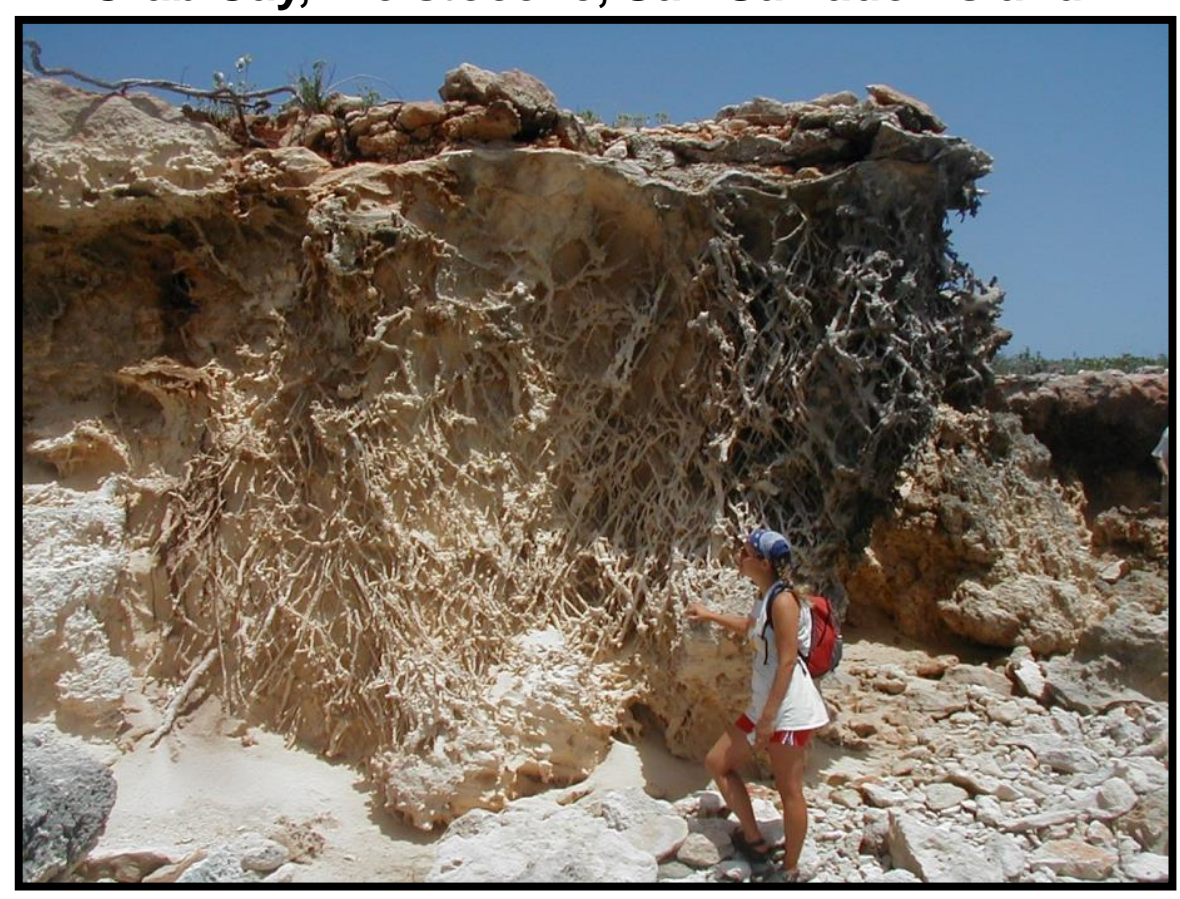

Presence or absence of root traces is not a function of wash-over scouring, but of temporal position in a sea-level highstand cycle. 
Another danger of climate change: Giant flying boulders?

Washington Post, November, 29, 2015, by science reporter Chris Mooney

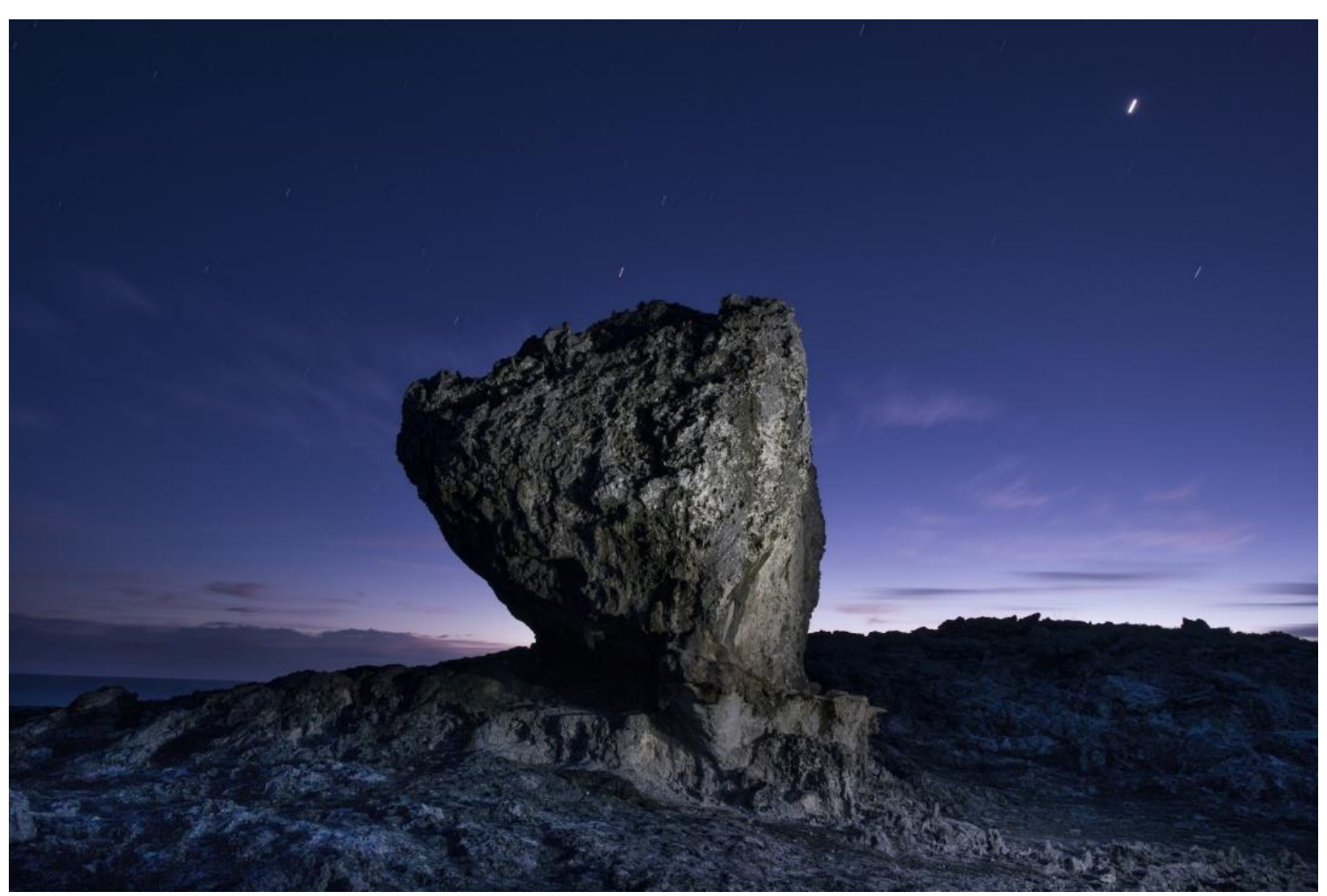


Another danger of climate change: Giant flying boulders?

Washington Post, November, 29, 2015, by science reporter Chris Mooney

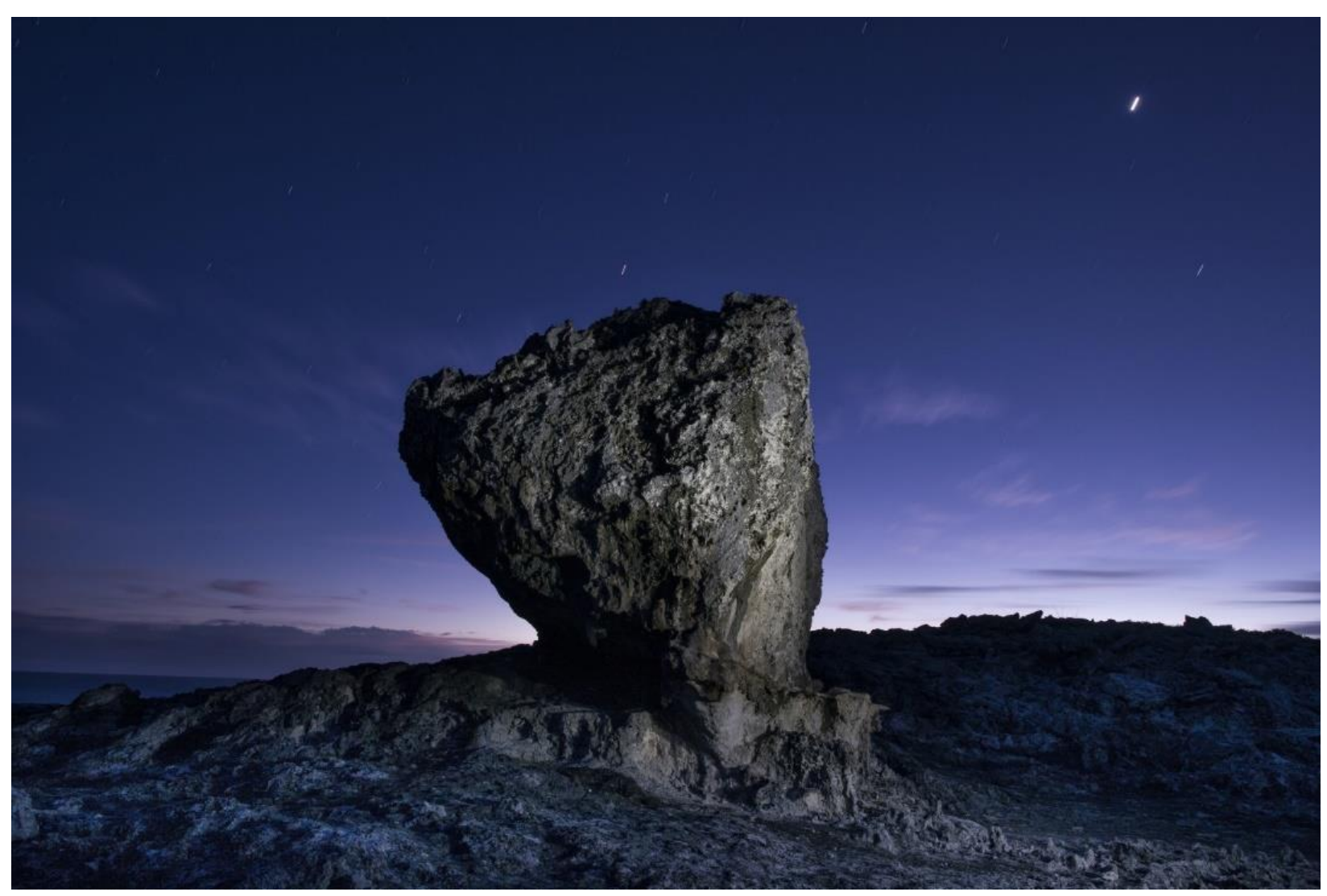

The article argues that these large boulders, and nearby calcarenite chevrons are the depositional evidence of a MIS 5e superstorm, and a warning about present-day climate change. 
There are 7 boulders (orange stars) described over an extent of a few kilometers, the most famous of which are the "Cow and Bull".

Eleuthera, Bahamas, Map Sheet 4, Lands \& Surveys Department, Nassau, Bahamas, 1970 
The hypothesis is based on previous work:

Hearty, P. J., 1997, Boulder deposits from large waves during the last interglaciation on north Eleuthera Island, Bahamas: Quaternary Research, 48, 326-338.

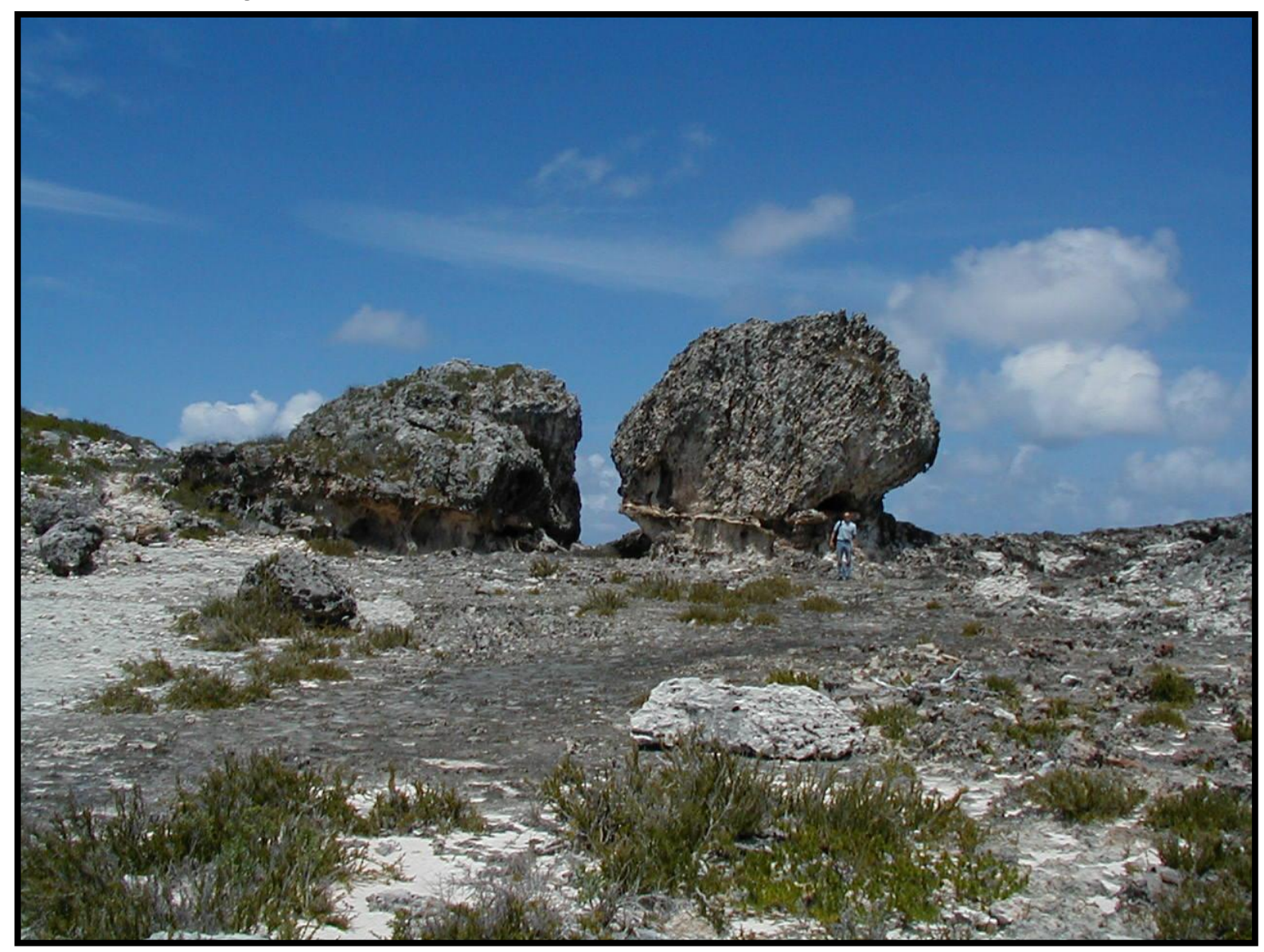

The Cow and Bull, Glass Window area, Eleuthera 
The hypothesis is that amino acid racemization (AAR) dating suggests the boulders are older than the surface they rest on; and have bedding and pendulous calcite in pores indicating they are not in depositional position. The interpretation is therefore they must have been flung into position by a tsunami or superstorm.

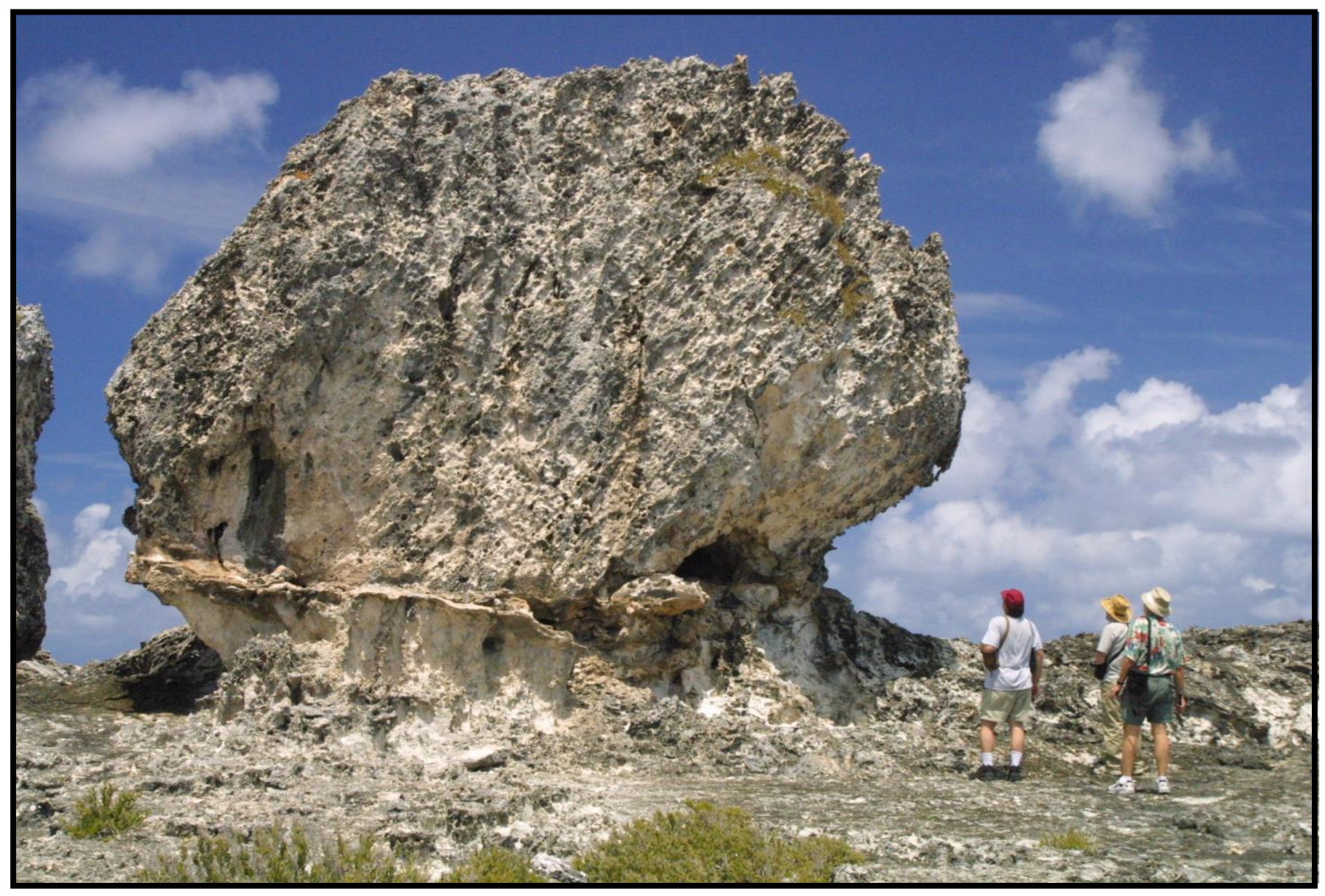


Alternative explanations have been offered:

1. The boulders are remnant tower karst

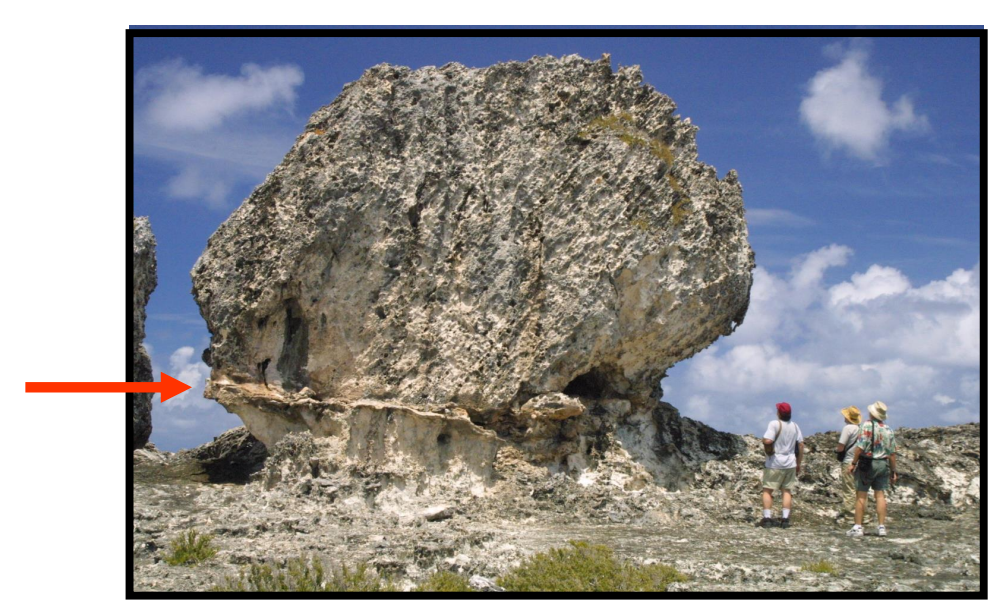

They are karrentisch, or "karst tables", sitting on an erosional pedestal (arrow).

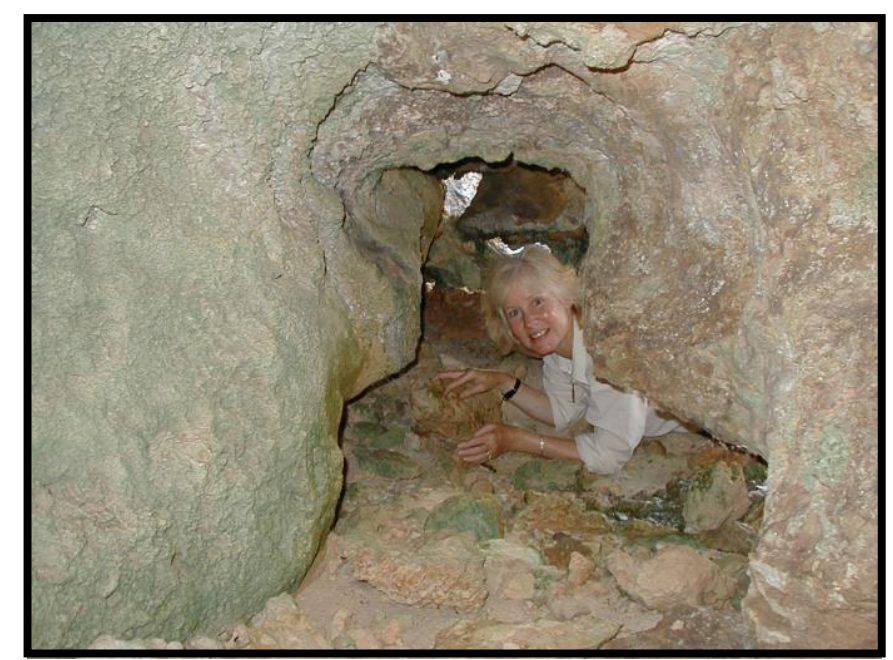

All the boulders have caves developed at their base

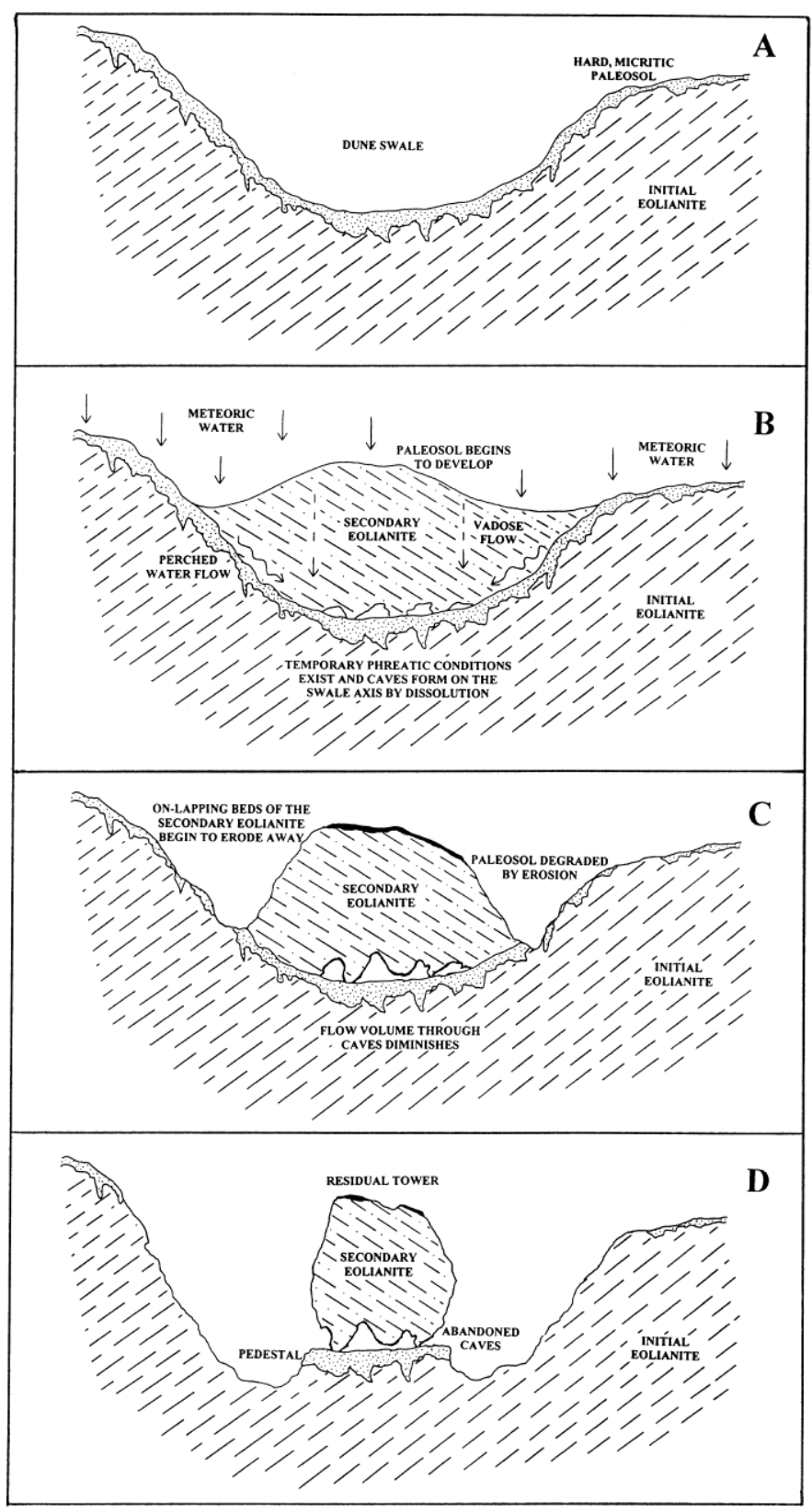

Mylroie, 2008 
Alternative explanations have been offered:

1. The boulders are remnant tower karst

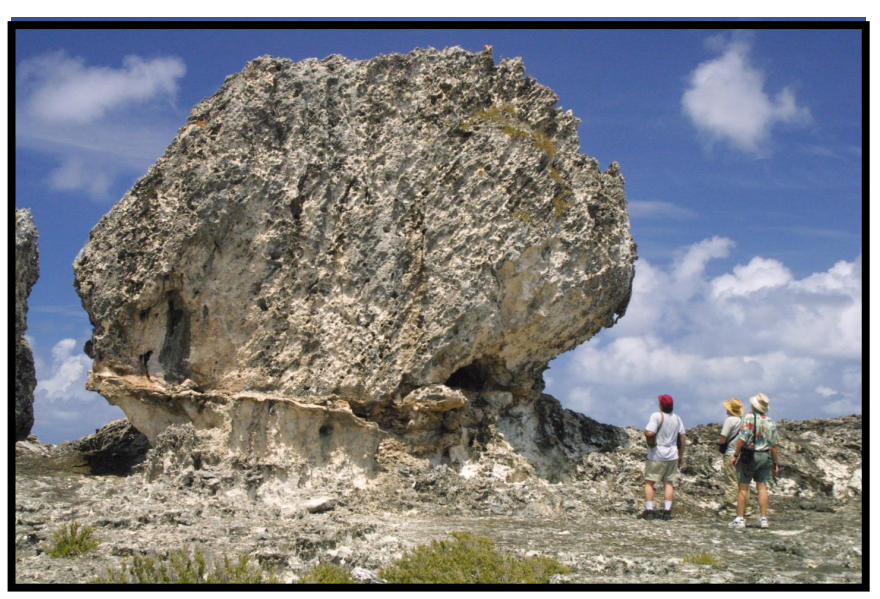

If the boulders have settled and rotated on their pedestals, then their bedding and pendulous calcite orientation can be explained.

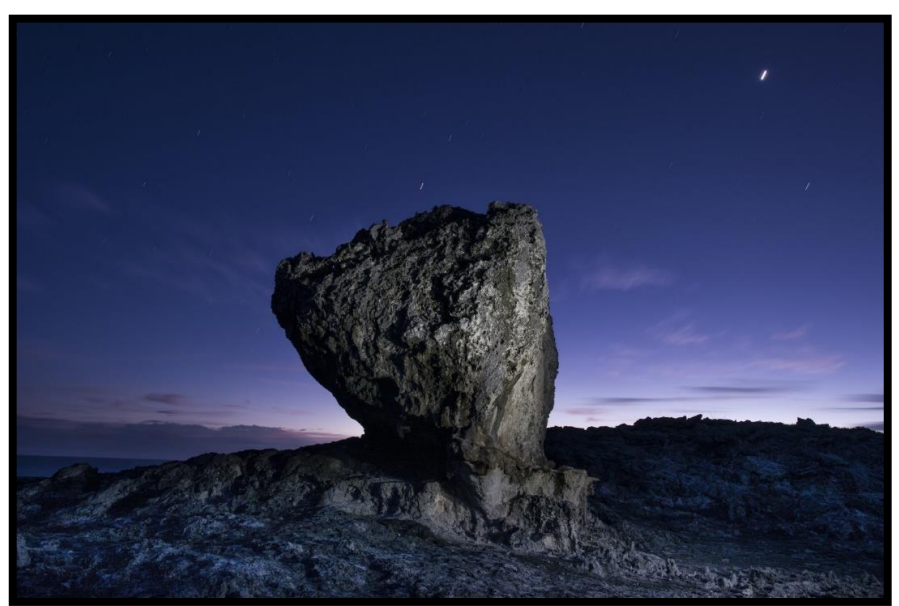

Washington Post, 2015

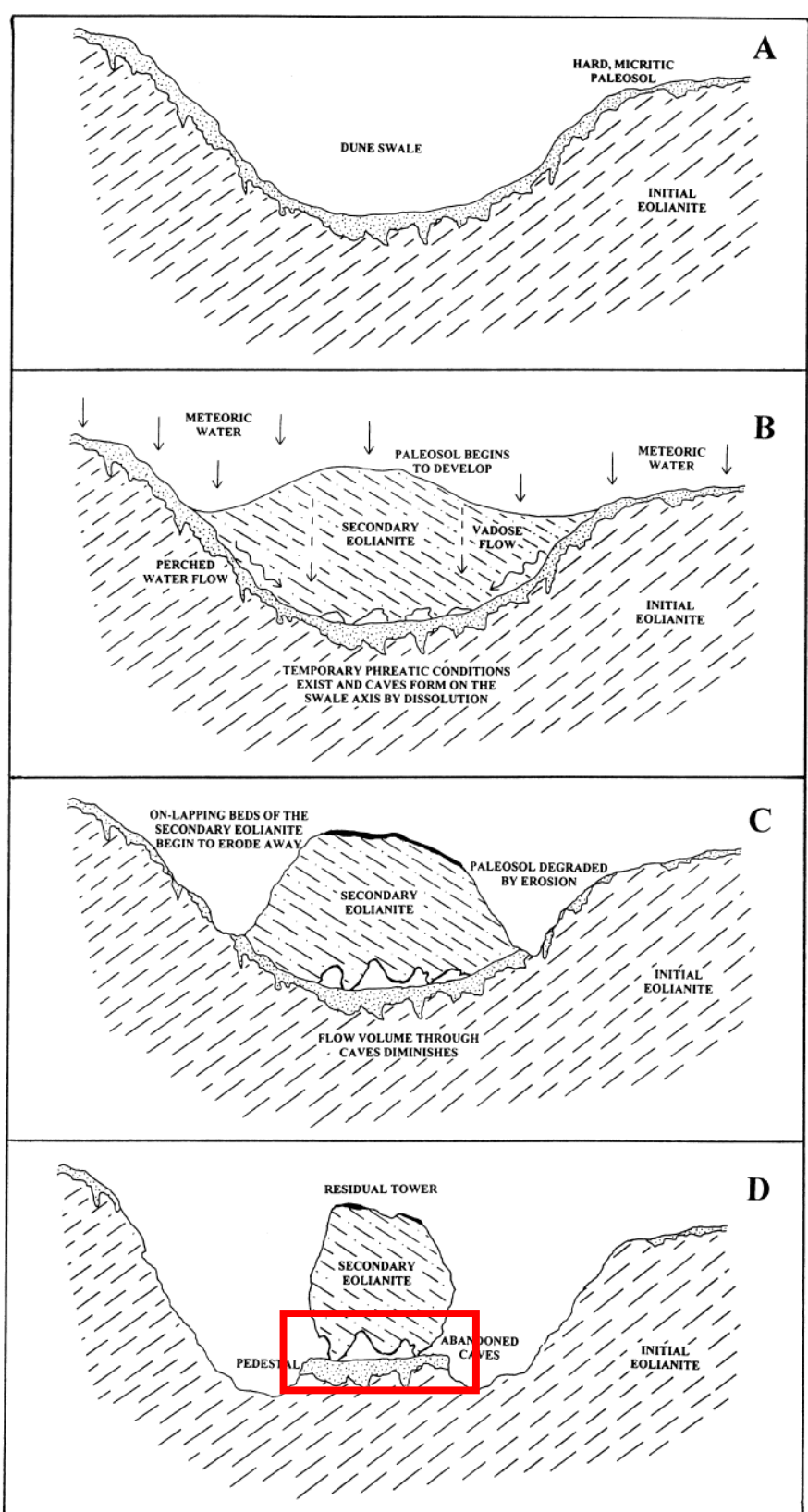

Mylroie, 2008 


\section{Boulder Three has split, and the fragments rotated independently}

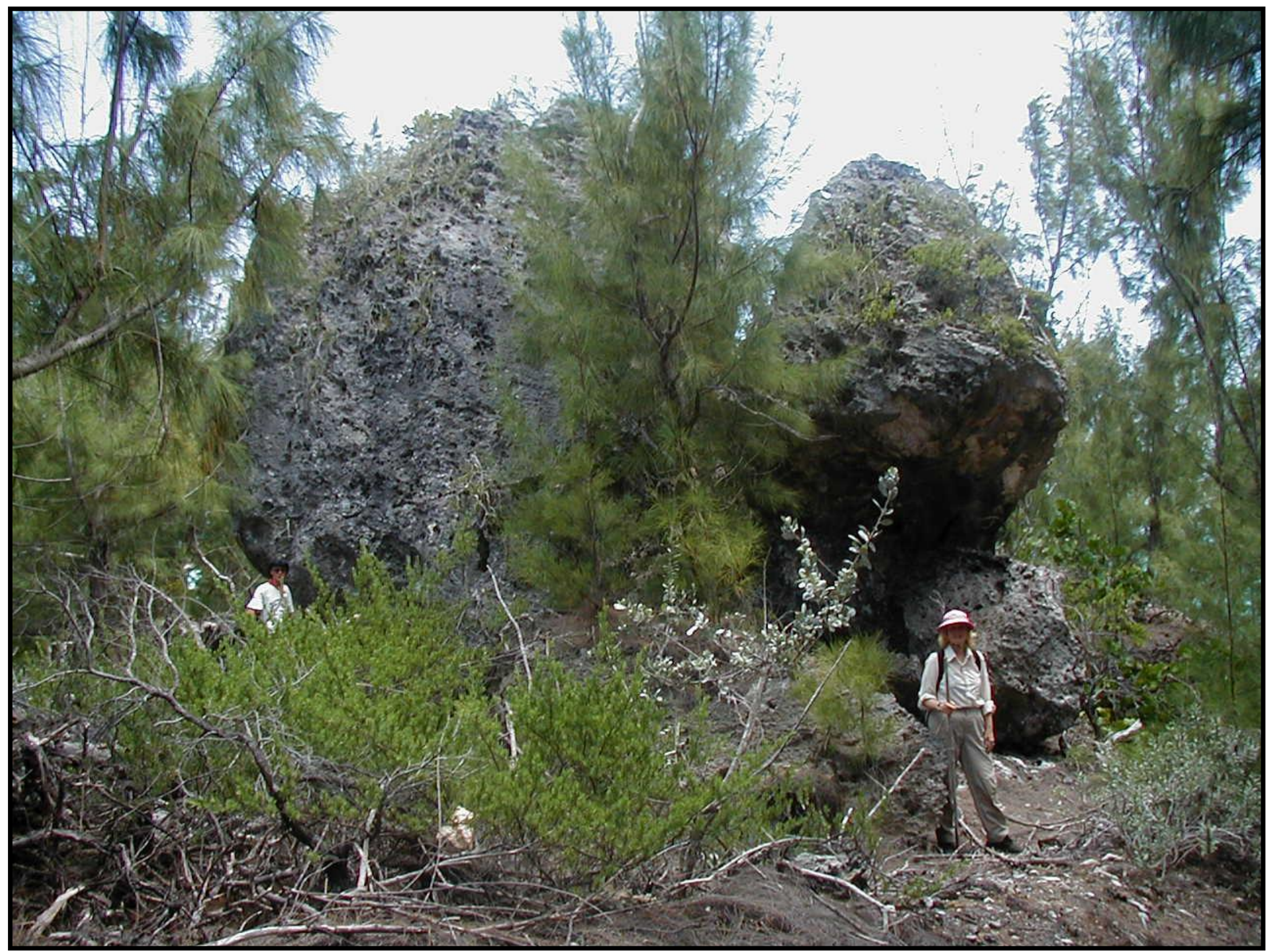




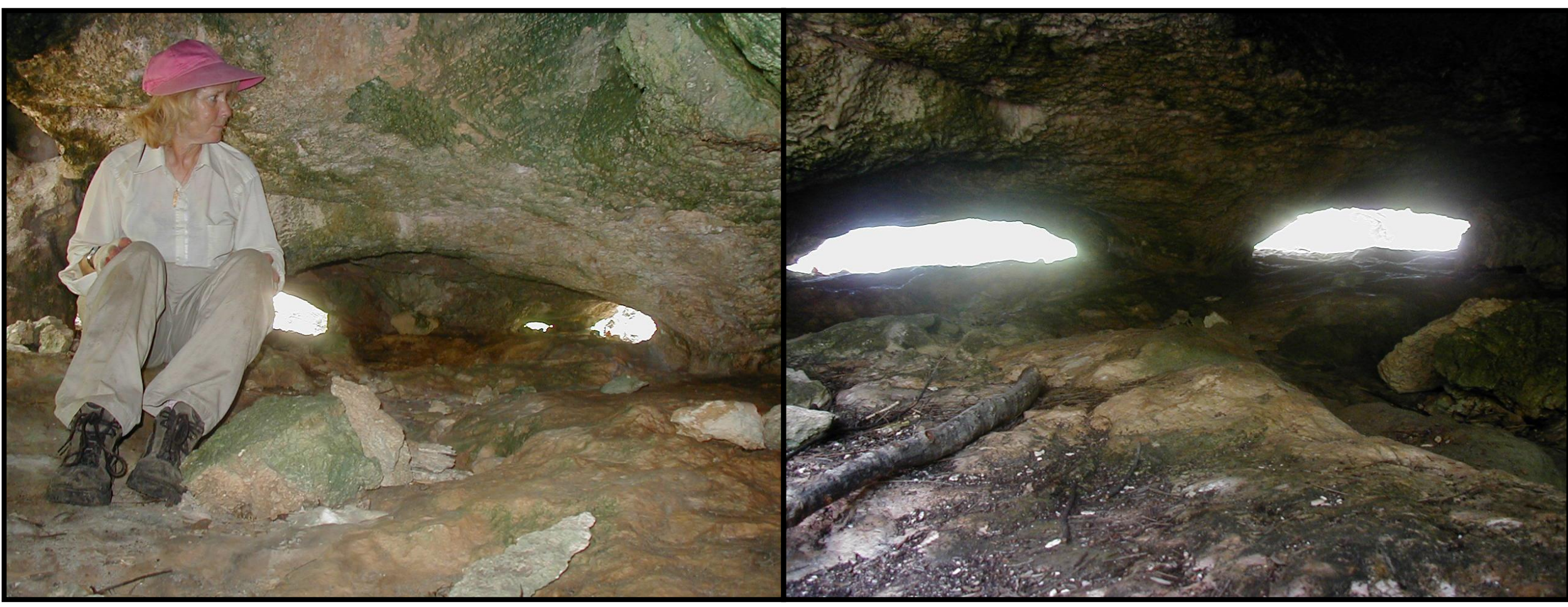

Boulder Three, like all the boulders, has a cave at its base, and the boulder rests on small pinnacles 
Alternative explanations have been offered:

1. The boulders are remnant tower karst

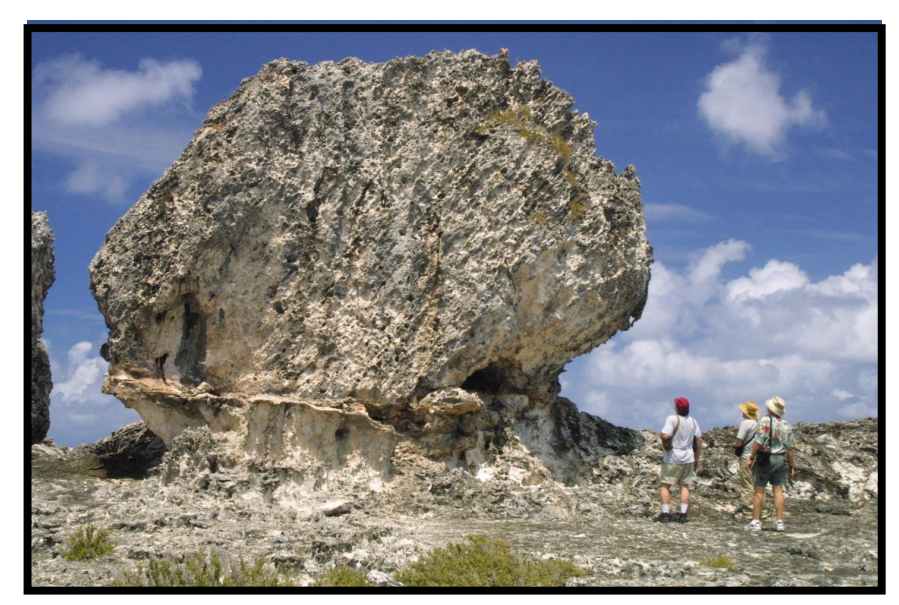

If the boulders have settled and rotated on their pedestals, then their bedding and pendulous calcite orientation can be explained.

Boulder expression as an exposed tower means their temperature regime would promote faster AAR, giving a false age inversion.

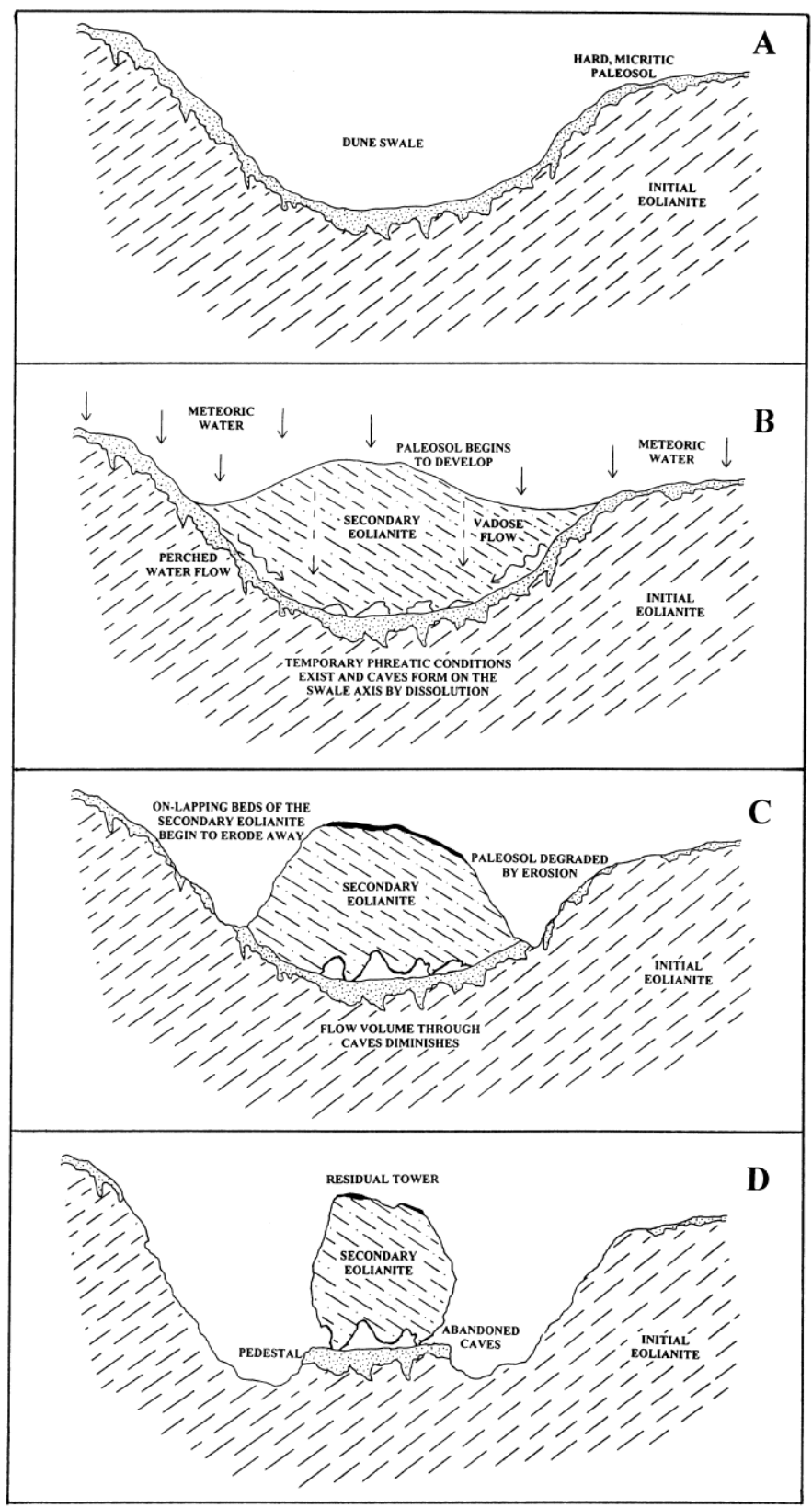

Mylroie, 2008 


\section{Alternative explanations have been offered:}

2. The boulders represent down slope movement from a previous shore line.

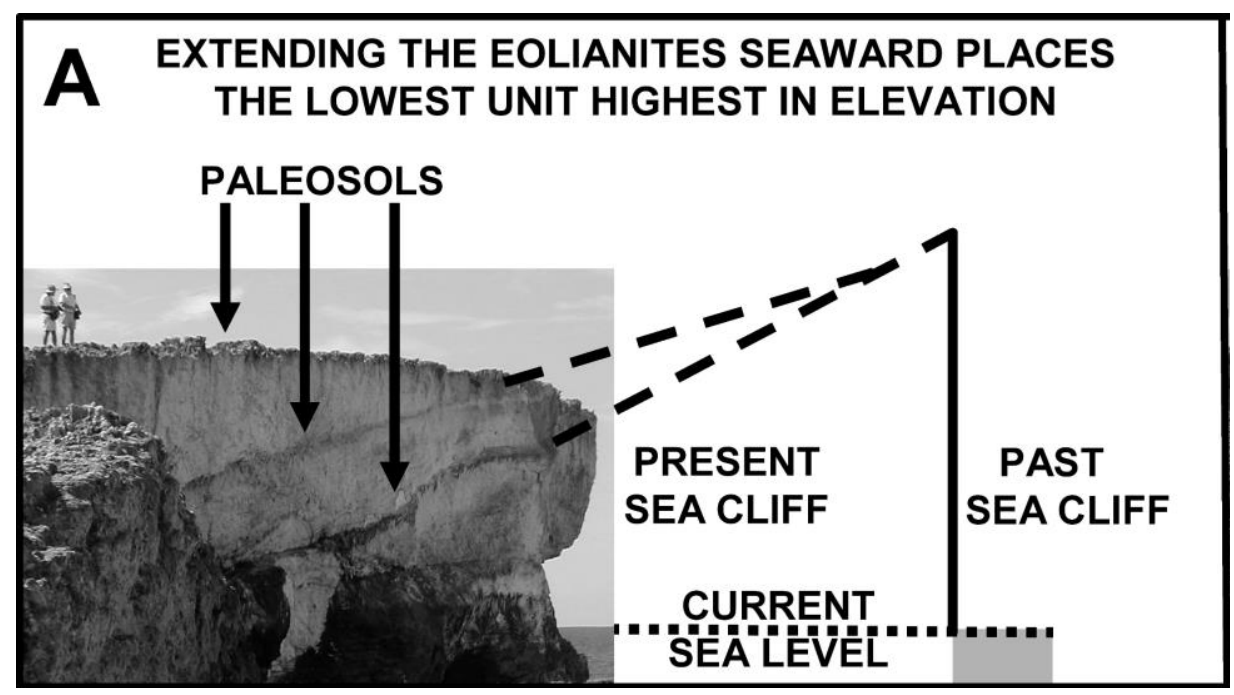




\section{Alternative explanations have been offered:}

2. The boulders represent down slope movement from a previous shore line.

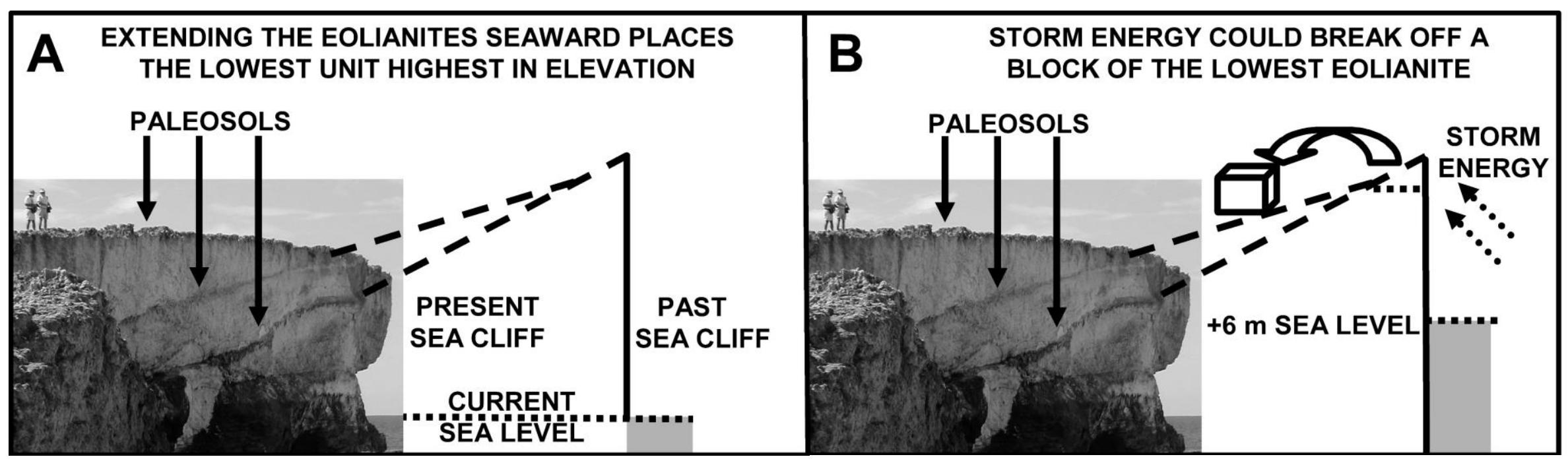




\section{Alternative explanations have been offered:}

2. The boulders represent down slope movement from a previous shore line.

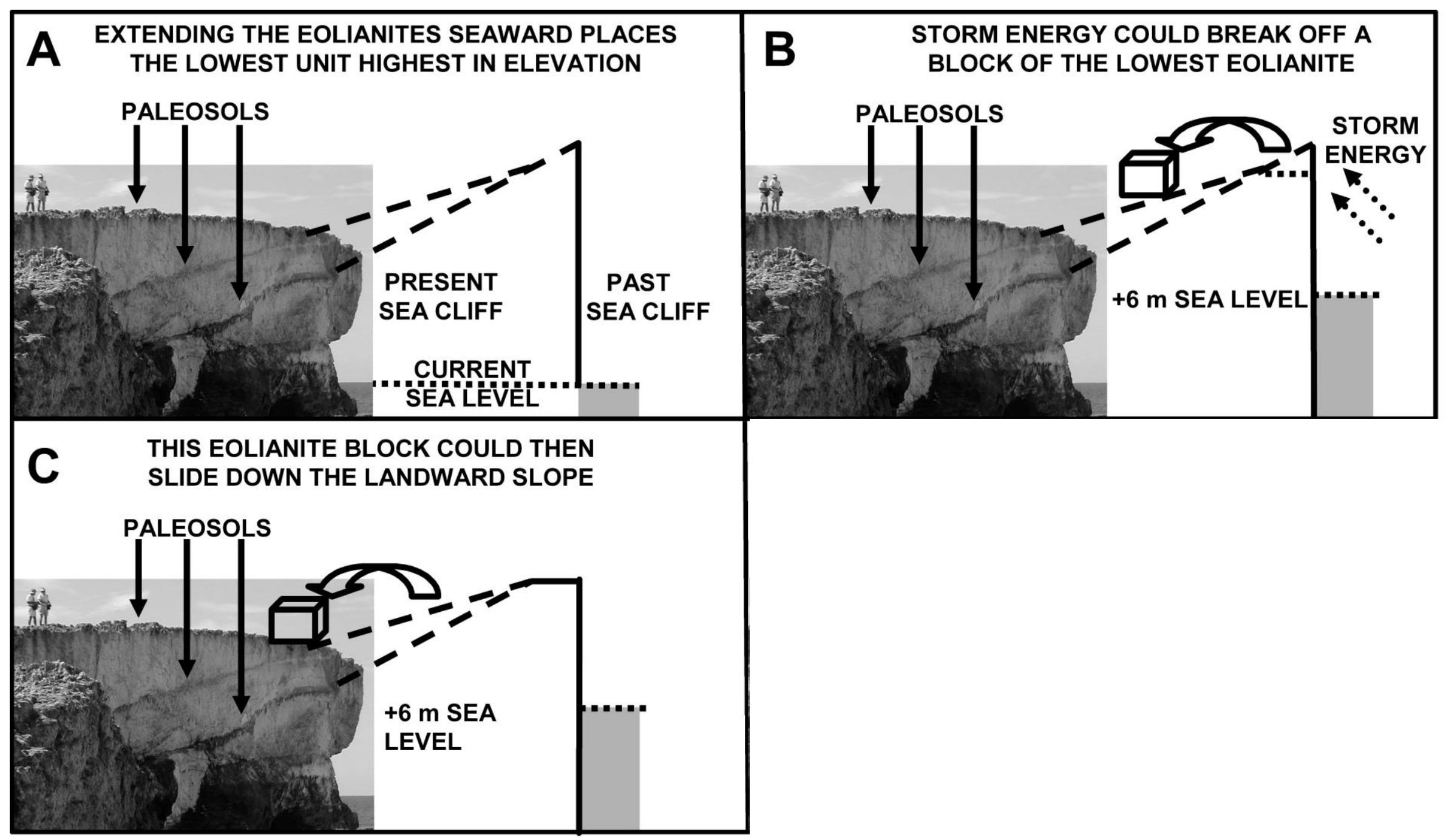

Mylroie, 2008 


\section{Alternative explanations have been offered:}

2. The boulders represent down slope movement from a previous shore line.

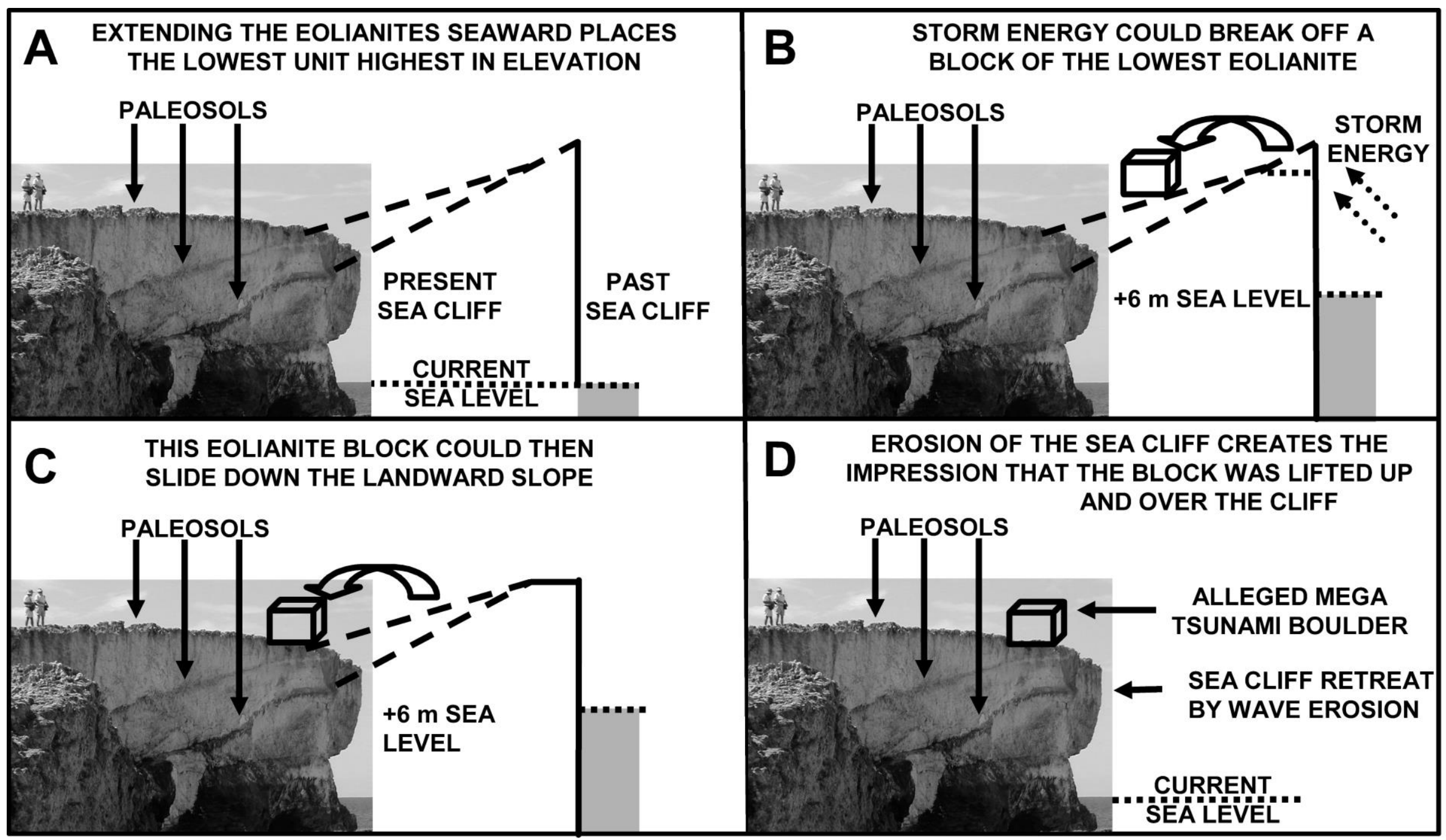

Mylroie, 2008 
The final problem involves the very small footprint of these boulders

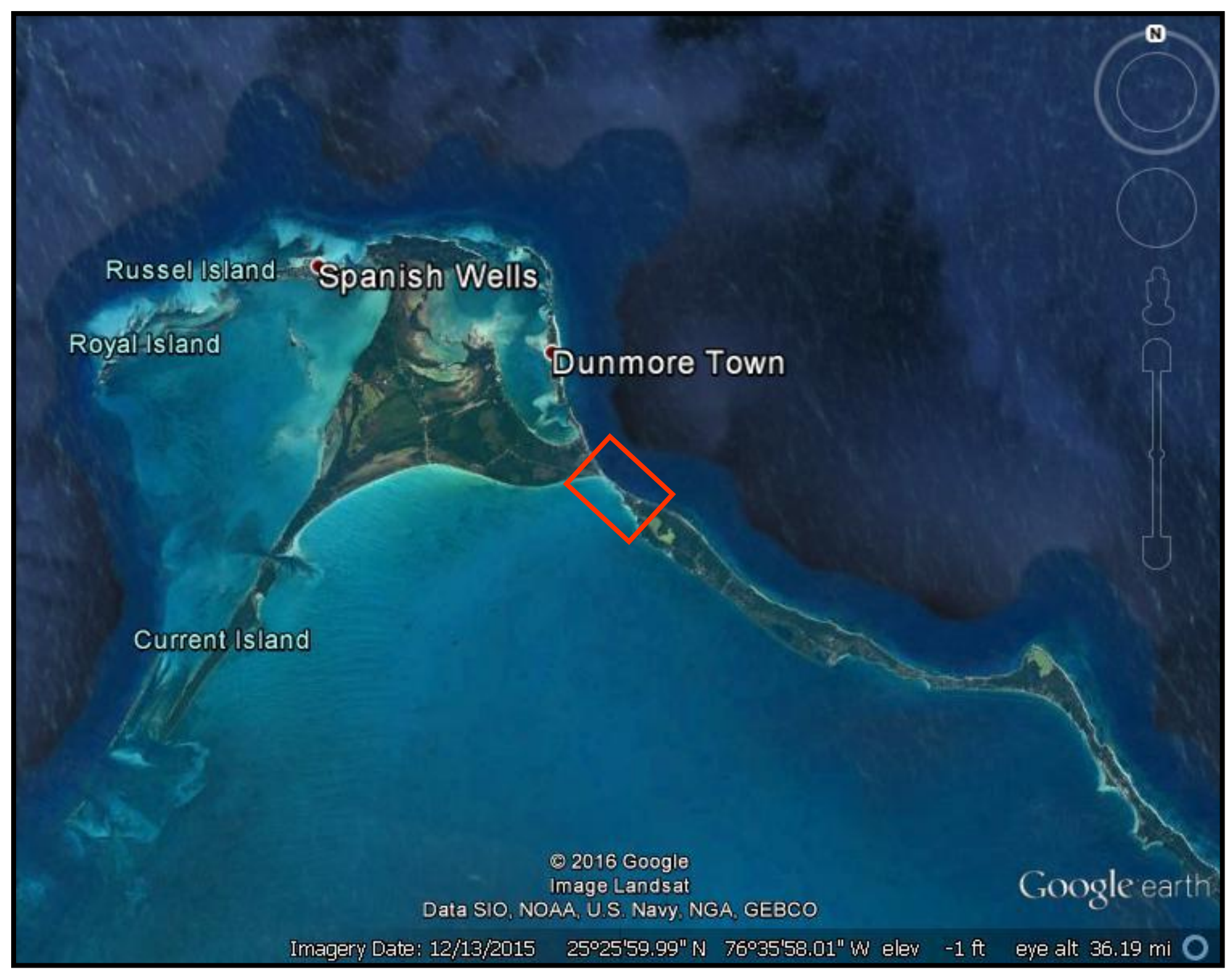


Intense hurricanes and superstorms have very large footprints. The entire straight-line size of Eleuthera is $125 \mathrm{~km}$ (red circles), the boulders are found in a footprint of only a few kilometers. No other boulders of this size are known elsewhere in The Bahamas.

Hurricane Katrina

Superstorm Sandy

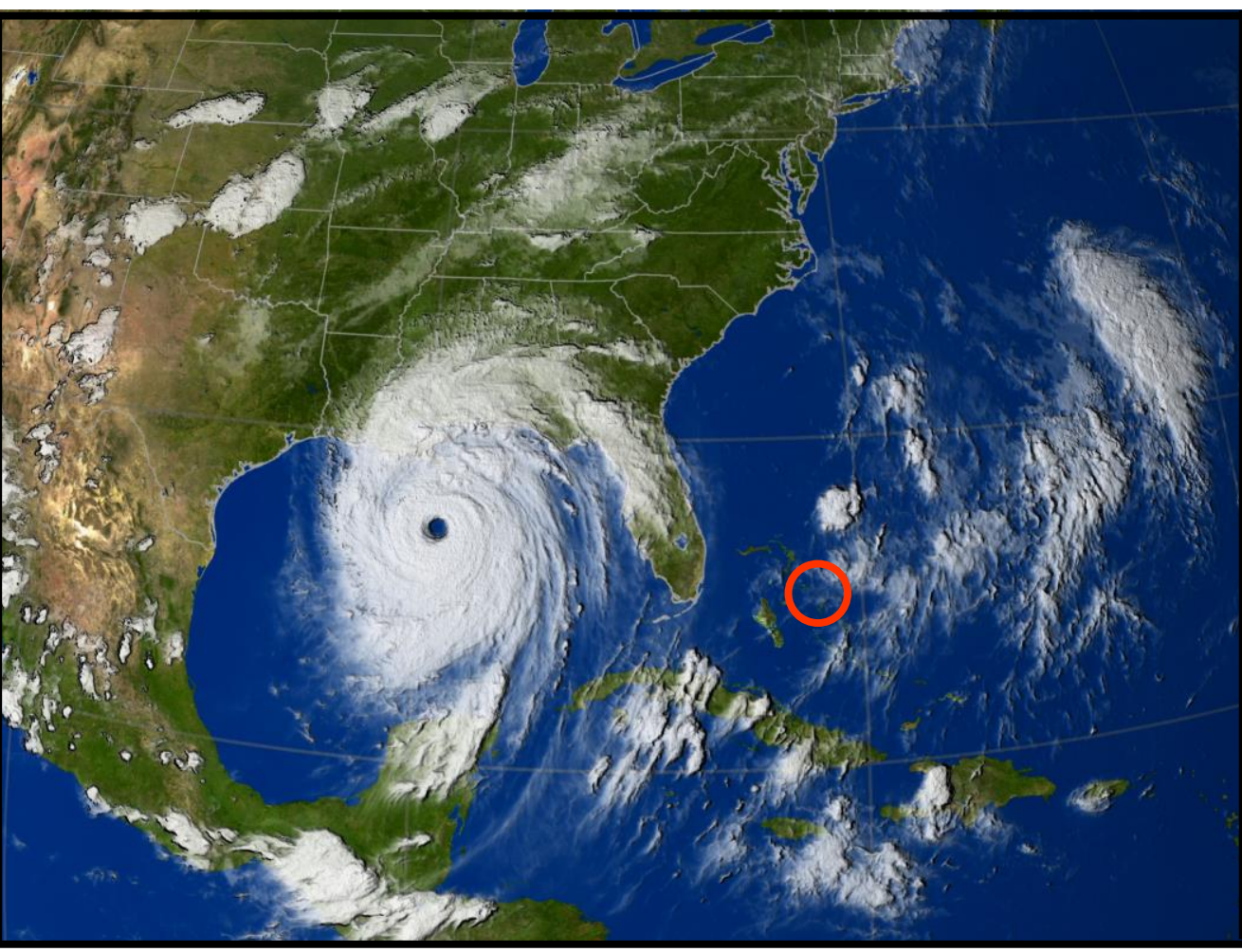

pics-about-space.com

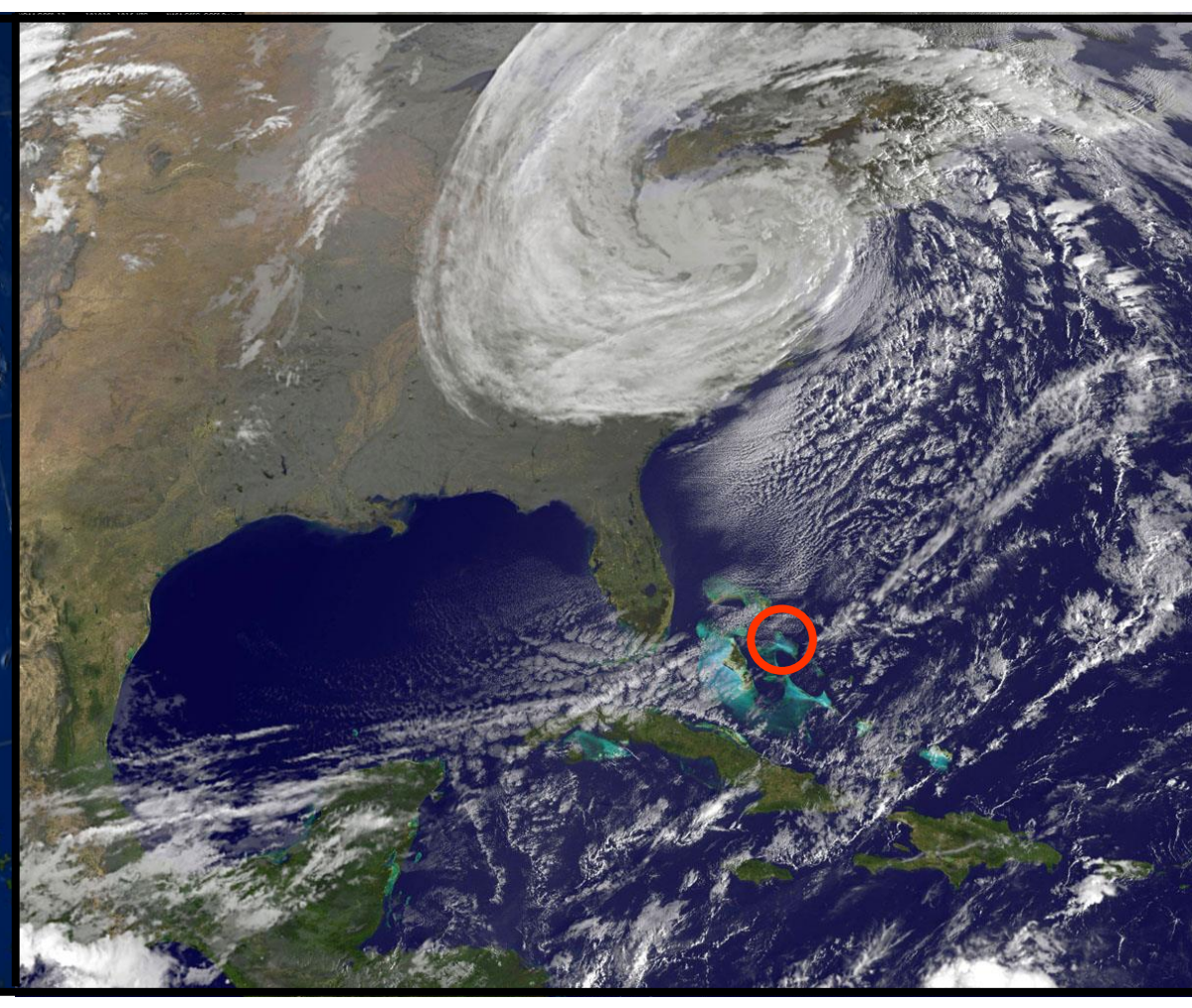

Livescience.com 
Hurricane Joaquin, early October, 2015, category 4, the largest to hit the Bahamas since 1866 (Berg, 2016).

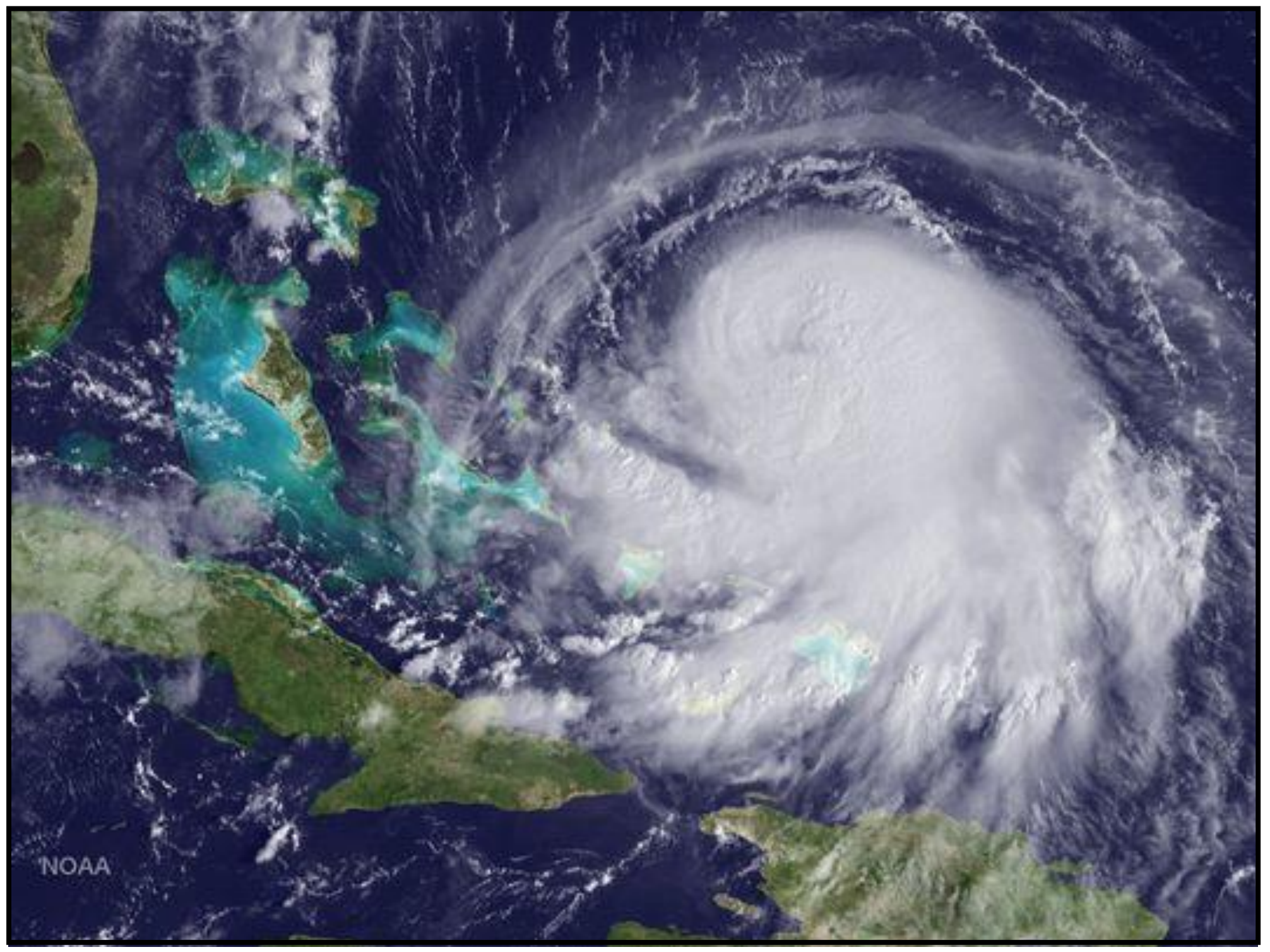


Hurricane Joaquin, early October, 2015, category 4, the largest to hit the Bahamas since 1866 (Berg, 2016).

Huge footprint, no boulders produced; red dot, Cow and Bull.

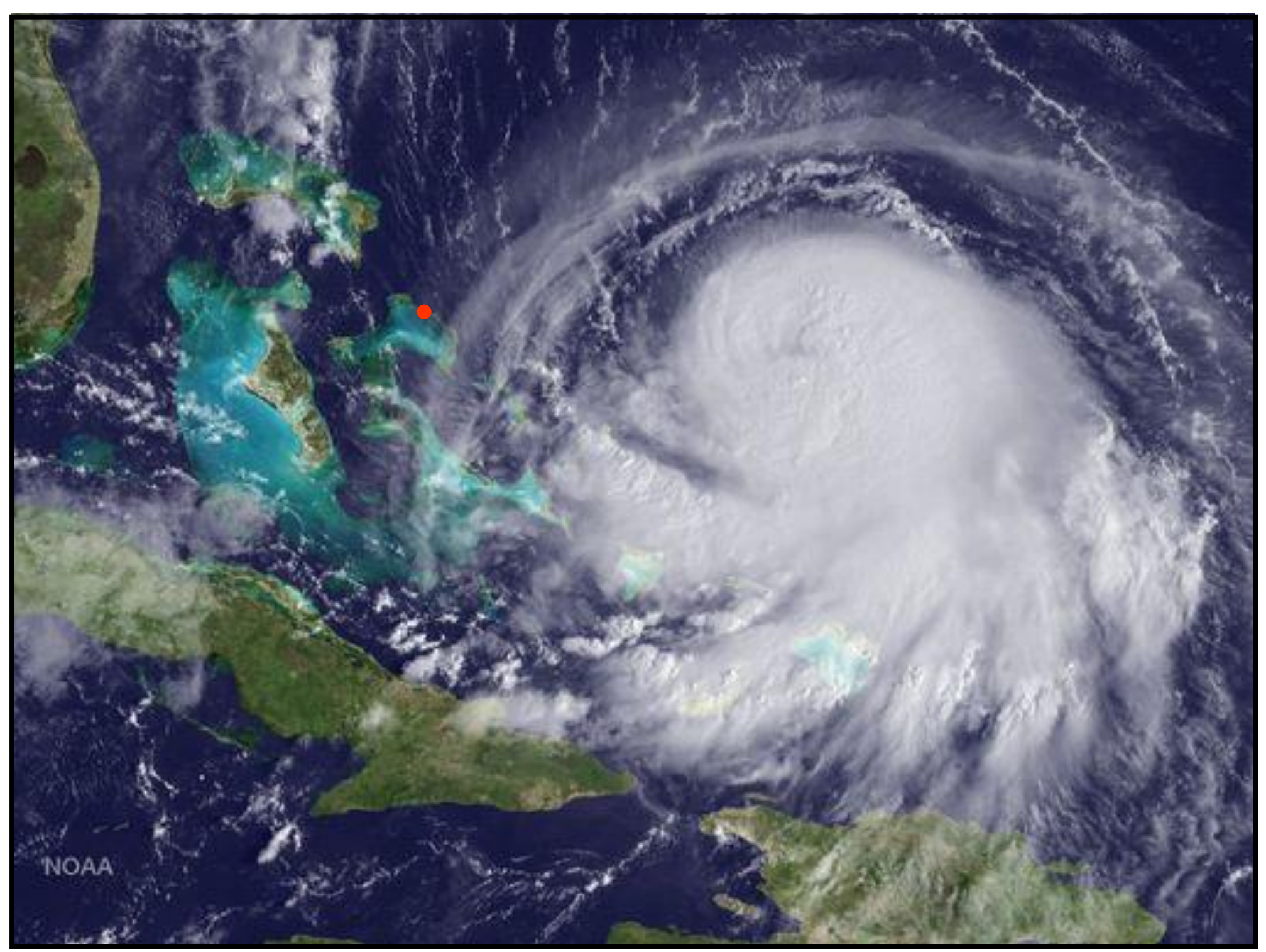




\section{CONCLUSIONS}

1. Fenestral porosity in Bahamian eolianites is a product of rainfall slurry, not superstorm washover.

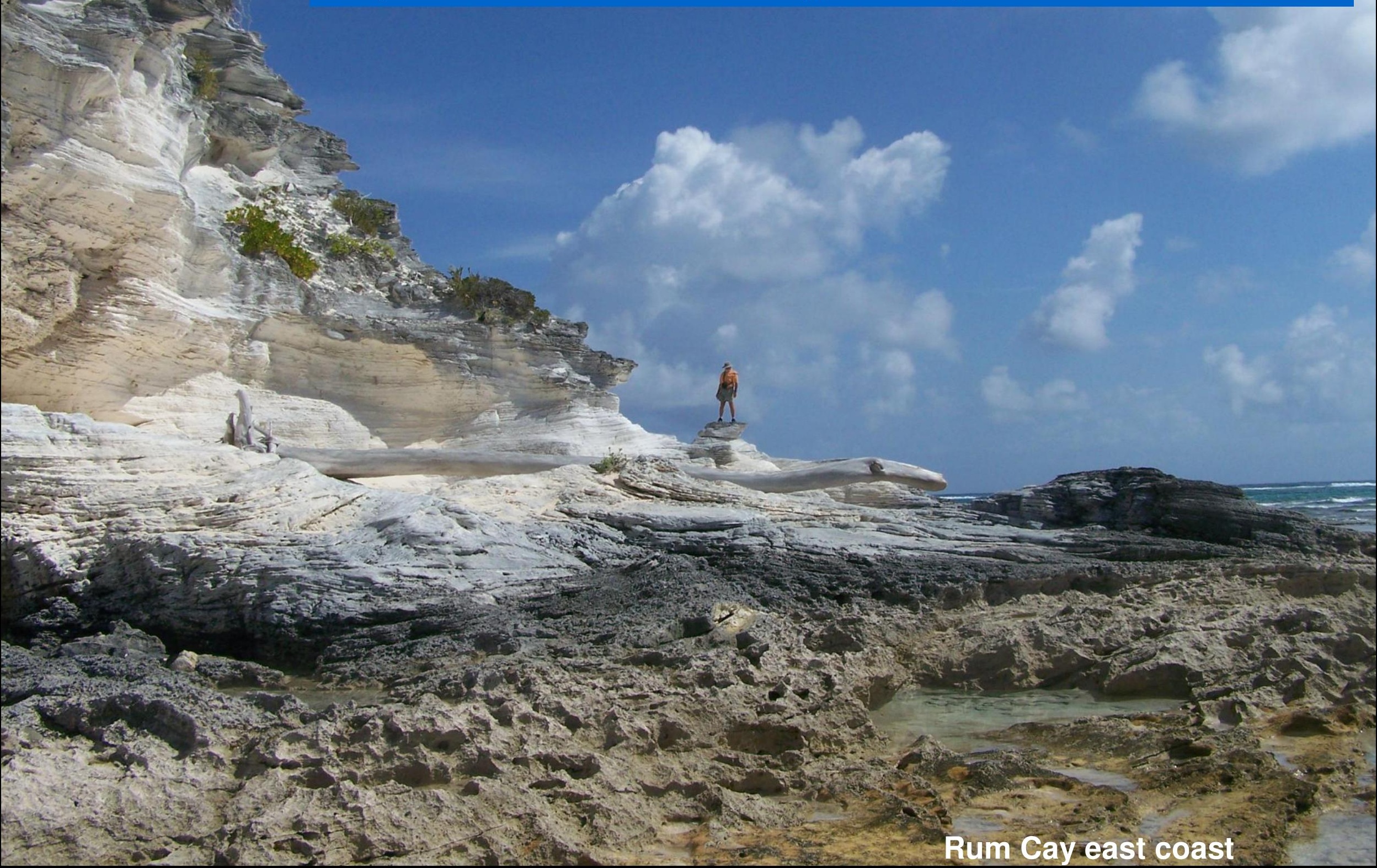




\section{CONCLUSIONS}

1. Fenestral porosity in Bahamian eolianites is a product of rainfall slurry, not superstorm washover.

2. Mega-boulders in north Eleuthera were not produced by a MIS 5e superstorm. 


\section{CONCLUSIONS}

1. Fenestral porosity in Bahamian eolianites is a product of rainfall slurry, not superstorm washover.

2. Mega-boulders in north Eleuthera were not produced by a MIS 5e superstorm.

3. The superstorm hypothesis is weakened by the lack of tempestites above $6 \mathrm{~m}$ asl

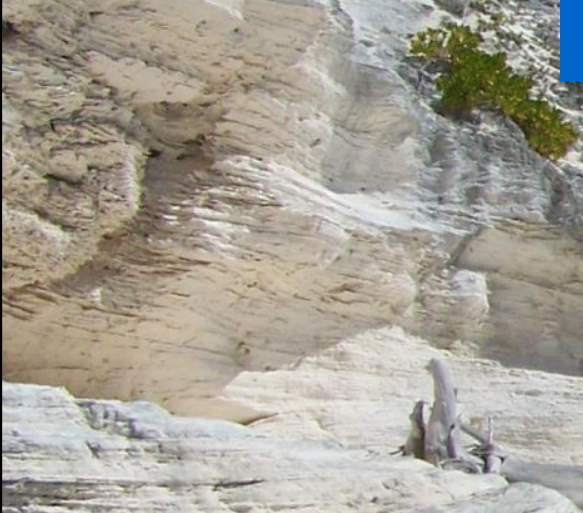




\section{QUESTIONS?}

Queen's Bath North Eleuthera

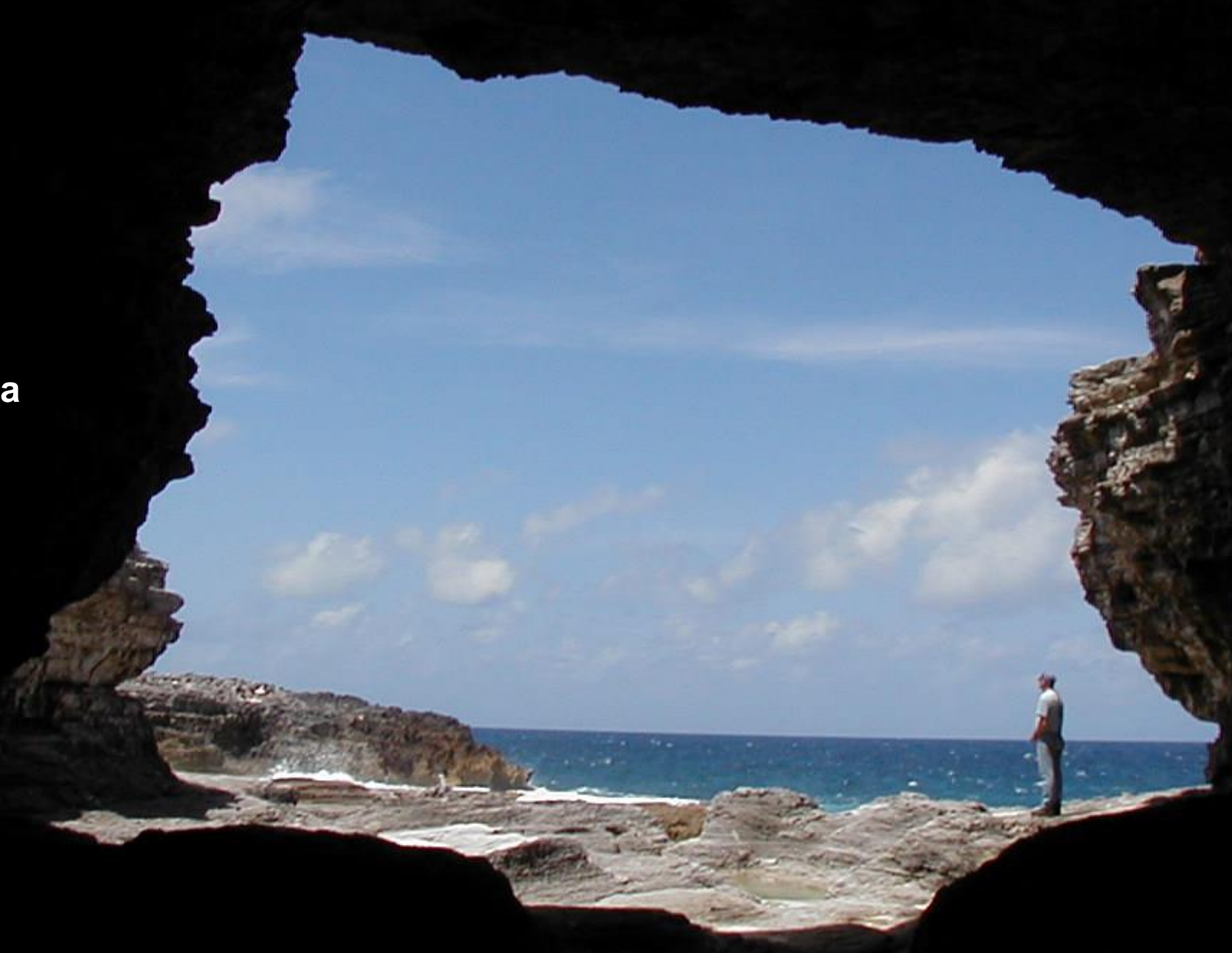

For the record, I fully believe climate change is happening; I just prefer good interpretations. My advice to students: "Don't buy coastal property". 